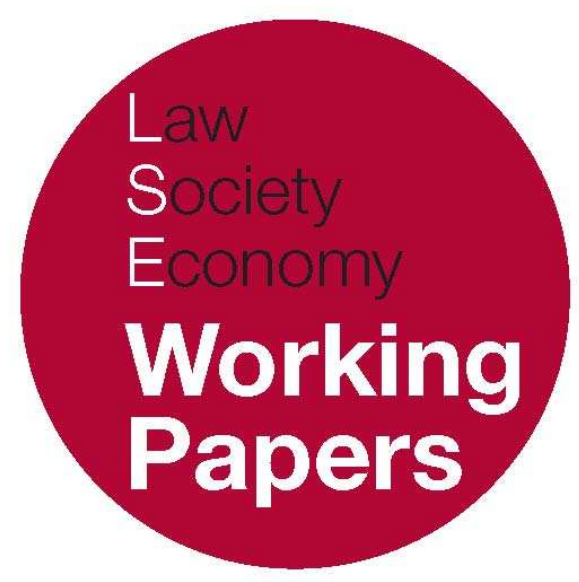

\title{
Lord Wright and Innovative Traditionalism
}

\author{
Neil Duxbury \\ LSE Law, Society and Economy Working Papers 11/2009 \\ London School of Economics and Political Science
}

Law Department

This paper can be downloaded without charge from LSE Law, Society and Economy Working Papers at: www.lse.ac.uk/collections/law/wps/wps.htm and the Social Sciences Research Network electronic library at: http://ssrn.com/abstract $=1418705$.

(C) Neil Duxbury. Users may download and/or print one copy to facilitate their private study or for non-commercial research. Users may not engage in further distribution of this material or use it for any profit-making activities or any other form of commercial gain. 


\title{
Lord Wright and Innovative Traditionalism
}

\author{
Neil Duxbury*
}

\begin{abstract}
This study presents the mid-twentieth century English lord of appeal, Lord Wright, as an innovative traditionalist judge. Judges have a duty to be creative, Wright believed, but only within the framework of existing legal authority. Wright explained his innovative traditionalist perspective in relation to precedent, public policy and legislation, and he illustrated his perspective particularly by way of contributions to decisions on worker compensation, commercial contracts, restitution and international criminal law. He was not always a bold judge, as is especially evident from his contribution to Liversidge v. Anderson. But his efforts to develop the law without undermining established precedents and statutory authority could be subtly effective. In contract and tort decisions he consistently argued that personal liability should attach only to outcomes which could reasonably have been expected to come about. He was realistic, and believed courts must be realistic, about the tendency of the business world to be guided primarily by its own norms. He incisively criticized implied contract theory and advanced a conception of unjust enrichment which, in England, was considerably ahead of its time. In employment law, he added a twist to freedom-of-contract reasoning, arguing that if it is permissible for individuals to use their economic advantage to impose contractual terms on weaker parties then it should also be permissible for those parties to combine and gain the upper hand. After World War II, he argued that the positive laws necessary for punishing war criminals already existed. This study draws these arguments together in an effort to capture Wright's judicial style and to show that some of his contributions to legal thought and doctrine run deep and are historically significant.
\end{abstract}

\section{INTRODUCTION}

Legal history remembers Lord Wright as one of the better rather than as one of the great twentieth-century English judges. He did not have Lord Atkin's boldness, or Lord Denning's iconoclasm, or Lord Reid's dynamism. He was rarely

* Law Department, London School of Economics and Political Science. 
pithy or memorable, and his speeches could, frankly, be ponderous and verbose. But it is not surprising that lawyers, particularly academic lawyers, remember him well, for he was earnest and reflective in his approach to all legal matters. The description of him as an 'innovative traditionalist' would probably have made him wince, though the idea behind the description would have struck him as obvious enough. An innovative traditionalist judge knows that judges cannot help but make law - that they are constantly restricting, extending or declining to apply particular legal principles in the light of new combinations of facts - but also that law imposes constraints on the judge's capacity to exercise this law-making function. The particularly adept innovative traditionalist judge is able, and will probably consider it akin to a badge-of-honour that he or she is able, to change the law quite radically while working (sometimes only just) within these constraints; he or she, as one judge has recently put it, will have ' $[t]$ he knack ... of reading cases and statutes creatively,' of exploiting 'the bag of rhetorical tricks ... that mark the legal insider' and of employing to good effect 'an ineffable sense ("judgment") of just how far one can go as a judge in changing the law ... to keep it abreast of changing social and economic conditions." Wright grasped all of this. He understood that a judge makes law within the terms of the law: that traditional principles of legal authority such as statutory supremacy and stare decisis do not preclude judicial creativity. He also believed, as did Lord Mansfield, that in commercial cases it is primarily by upholding recognized mercantile traditions, rather than by interpreting or distinguishing applicable rules, that judges have the opportunity to be creative. The purpose of this study is to present Wright as an exemplary purveyor of innovative traditionalism.

Exemplary but not unique. Innovative traditionalism was, for English judges of Wright's era, a skill developed out of necessity: the decisions of the court of final appeal were irreversible other than by the intervention of Parliament, and so the courts would sometimes have to distinguish the life out of an unfortunate precedent because they could not overrule it. ${ }^{2}$ Even among Wright's generation there were other appeal court judges in England - Atkin, du Parcq, Macmillan, possibly Russell - who could fairly be described as deft practitioners of innovative traditionalism, certainly if we take that term to apply generally to judges who sought to renovate or develop particular principles and doctrines. Indeed, if we were to retreat and assess the broader landscape we would soon conclude that there are many other judges no less of this type and no less intriguing - and that there are some who are perhaps rather more intriguing - than Wright. Most likely the first person who would have counselled against a study of Wright would have been Wright himself. Judges, unlike jurists, he recognized, are usually reacting to the legal problems put before them rather than addressing the problems that interest them. 'When at the end it is attempted to evaluate what it all amounts to,'

\footnotetext{
${ }^{1}$ R. A. Posner, How Judges Think (Cambridge, Mass.: Harvard University Press, 2008) 209.

${ }^{2}$ Consider, e.g., the treatment of Derry v Peek (1889) 14 App. Cas. 337 (H.L.) in Nocton v Lord Ashburton [1914] A.C. 932 (H.L.).
} 
he wrote by way of assessment of Atkin, 'there will be no great scientific discoveries to record, no massive volumes of history or literature or speculation to point to.' ${ }^{3}$ Most judges will tend to pick up and quickly drop ideas and concepts in accordance with what is before the court, rather than explore those ideas and concepts systematically.

But it is also true that many judges will have areas of law in which they excel more than others, and that they will have the opportunity over time to develop particular lines of legal reasoning. This was certainly so with Wright, who not only used his judgments to set out his interpretations of principles and doctrines in areas which were regularly in his sights while he was at the Bar but who also produced a considerable body of speculative literature akin to that which an academic lawyer might produce. He contemplated a university career, compiled a collection of legal essays, regularly wrote for law reviews, and was more academically minded than not only the judges of his generation in England but most of the legal academics as well. And while the legal problems which he addressed were not of his choosing, they were tough and perennial: the status of civil liberties during war-time and the legal capacity of the international community to punish perpetrators of crimes against humanity, along with less high-profile instances such as the employer-employee relationship and the determination of principles by which to settle disputes over unperformed contracts. His approach to these problems was analytical and, usually, progressiveminded. That other judges deserve their day in the sun is no reason to deny Wright his, even if he might have spurned it.

This study begins with an overview of Wright's life and early career. It then offers an account of what I characterize as his innovative traditionalist perspectives on precedent, public policy and (paying particular attention to Wright's efforts to expand the range of protections afforded to employees) statute law. At the centre of the study is a section tracing Wright's contributions to the law on causation, foreseeability, frustration, commercial contracts and restitution. His contributions in all of these areas build on the premise that a person should not be held responsible for that which transpired but which nobody might reasonably have anticipated. The arguments he develops are often complex and idiosyncratic, and do not always meet with success. Taken as a whole, however, they can be seen to have had a significant impact on the law of obligations, particularly on contract law and restitution, and constitute his primary legacy to common-law jurisprudence.

Not that Wright was always innovative. Some of his arguments can be found in Mansfield. Nor was he always bold, as is clear from some of his Privy Council contributions and, some would say, the position he took on the use of powers of detention during World War II. If there was sometimes a lack of boldness, however, there was no lack of seriousness. He was sufficiently candid to admit to

3 Lord Wright, 'Lord Atkin of Aberdovey, 1867-1944' (1944) 60 L.Q.R. 332, 332. (Hereafter 'Atkin' (L.Q.R.)). 
errors he felt he made on the Privy Council, and he recognized that the decision to suspend habeas corpus during the War could not be taken lightly. He also, at the end of his career, turned his attention to one of the most profound moral problems that the War bequeathed to the allied nations: how to punish military atrocities. This last problem brought out a natural lawyer in Wright, though one who remained convinced that punishments must be determined according to what is permissible within positive international law.

\section{WRIGHT'S CAREER}

Robert Alderson Wright was born on 15 October 1869. It is not clear what he did with his life until he matriculated at Trinity College, Cambridge, in 1893 at the age of 24. He grew up in South Shields (in north-east England), where his father was a marine superintendent, and his Who's Who entry states no more than that he was educated privately. ${ }^{4}$ Though Wright died with the wealth of a successful lawyer (probate records a figure of $£ 87,746$ in 1964), money seems not to have been much in evidence very early in his career. He described himself to an American audience in 1936 as 'a mere working lawyer ... who went into law chambers without a proper academic learning in law,, 5 but he omitted to tell that audience what few of them would have realized - that hardly any English lawyers of his generation had an academic learning in law.

He obtained a First in Classics and Moral Science in 1896, and three years later Trinity College awarded him a six-year fellowship. ${ }^{6} f 200$ per year attached to the fellowship (which required him to do nothing in particular), and this supported him in his day job - he had been admitted to the Inner Temple in November 1896 and was called to the Bar in June 1900 - though it did not support him sufficiently. ${ }^{7}$ Wright was a pupil, along with Atkin, in the chambers of Thomas Scrutton. The environment was austere and Scrutton intemperate ${ }^{8}$ - qualities

\footnotetext{
${ }^{4}$ The admission register at the Inner Temple (ADM/4/27) records that 'Robert Alderson Wright, aged 27, of Trinity College, Cambridge, BA, and of 18 Eleanor Street, South Shields, the only son of John Wright of 18 Eleanor Street, South Shields, civil servant was admitted to the Inner Temple on 7 November 1896.' The Inner Temple's Bar book (BAR/4/1) records that Wright was called to the Bar on 27 June 1900, and as elected as a Bencher on 20 November 1923. It also notes his appointment as KC on 28 July 1917; Judge on 22 May 1925; Lord of Appeal on 12 April 1932 and Master of the Rolls on 7 October 1935.

${ }^{5}$ Lord Wright, Legal Essays and Addresses (Cambridge: Cambridge University Press, 1939) 327 (hereafter $L E A)$.

6 The college made him an honorary fellow in 1939: Hugh McLeod Innes, Fellows of Trinity College (Cambridge: Cambridge University Press, 1941) 15.

7 See A. L. Goodhart, 'Lord Wright, 1869-1964' (1965) 51 P.B.A. 429, 429-430.

8 See www.oxforddnb.com/view/article/35998 (visited 9 July 2008), where F. D. Mackinnon's ODNB entry for Scrutton (revised by Hugh Mooney) records that 'Scrutton got through an immense amount of work ... in the hideous room which he occupied in the hideous block called Temple Gardens, and in which a Spartan rigour reigned. Scrutton sat on a Windsor chair, without a cushion, at a battered writingtable.... When darkness set in, the only source of light was a Victorian chandelier with fishtail gas
} 
which Wright himself appears to have exhibited in his early career. Harold Laski wrote to O. W. Holmes in 1925 of how a solicitor acquaintance recalled Wright as having been the worst-mannered man at the bar.9 ' $[\mathrm{H}]$ is advocacy,' Wright's Times obituary reports, 'was lugubrious rather than brisk. ${ }^{10}$ Patrick Devlin's description of Wright brings to mind one of Wright's heroes, the notoriously taciturn Frederick Pollock: 'though a great lawyer, ... no orator; indeed, ... the master of the monotone sinking sometimes to the mumble."11

Pollock was a failure as a barrister, and for a while it looked as if Wright would be too, and that he would negotiate the failure in much the same way as Pollock had. After a decade in practice, according to Wright's ODNB entry, his opportunities to work were so meagre that he was considering becoming a fulltime academic. ${ }^{12}$ That path was certainly available to him. In 1903, he had become the second ever lecturer to be appointed to teach Industrial and Commercial Law at the London School of Economics. ${ }^{13}$ His course, thirty lectures plus optional weekly classes over the three terms, originally ran on Friday evenings with a 50 per cent discount for full subscription (the fee was 10 shillings for 10 lectures or 15 shillings for the full course). ${ }^{14}$ The lectures examined, among other things, the contract of employment, consideration, employees' rights, the 'legal status of trade

burners. The other two rooms were filled with "devils" and pupils, including, at various times, the future Lord Atkin, Lord Wright, Lord Justice MacKinnon, Mr Justice Fraser, and Mr Justice Henn Collins. At $4.15 \mathrm{pm}$ the group met together for some repulsive tea and dry Bath Oliver biscuits. Scrutton, silently absorbed in thinking about his work, would stride about the room until, almost daily, the top of his head crashed into the knob of the chandelier that hung from the ceiling.' Scrutton's Times obituary writer observed how Scrutton's 'brusqueness of manner, irritability and petulance impaired the dispatch of business in his Court... [A]n active protest was made on behalf of the solicitors .... against the rudeness with which they were treated in chambers.... His faults ... may perhaps be attributed to a mind working with great rapidity ... which was unable to suffer fools (or others who disagreed with him) gladly'. Anon, 'Sir Thomas Scrutton: Lord Justice of Appeal' The Times (21 Aug. 1934) p.7. His capacity for causing offence probably explains why, as a judge, he did not progress beyond the Court of Appeal.

${ }^{9}$ H. J. Laski to O. W. Holmes, Jr., 20 July 1925, in Holmes-Laski Letters: The Correspondence of Mr. Justice Holmes and Harold J. Laski 1916-1925, ed. M. DeWolfe Howe, 2 vols. (Cambridge, Mass.: Harvard University Press, 1953) at I, 767

10 Anon [A. L. Goodhart], 'Lord Wright: Former Lord of Appeal' The Times (29 June 1964) p.15.

${ }^{11}$ P. Devlin, The Judge (Oxford: Oxford University Press, 1981) 112. It seems he did not improve with age: see William C. Van Vleck to James M. Landis, 20 July 1938 ('His material is splendid but ... [w] hen he undertakes to read a speech, he swallows his words or speaks in a low voice'), and J. M. Landis to W. C. Van Vleck, 29 July 1938 (I quite agree with you that his stuff is good but his delivery is poor'), in E.S. Griswold Papers, 1925-1994, Harvard Law School Library, Special Collections, series XVII, subseries E, sub-subseries 1, folder 305-4.

12 See also Lord Wright to E.S. Griswold, 20 June 1950, in Griswold Papers, XVII. E. 1: folder 305-4 ('Eventually I had to decide between a practising or academic career in law, and chose the former').

${ }^{13}$ In 1901-02 and 1902-03 the course was lectured by J. A. Simon: see London School of Economics and Political Science: A Brief Abstract of the Programme for the Session 1901-02 (London: n.p., 1901) 77; London School of Economics and Political Science: Sessional Programme 1902-1903 (London: LSE, 1902) 19.

${ }^{14}$ See London School of Economics and Political Science: Calendar for the Session 1903-04 (London: LSE, 1903) 81. Many LSE students of this period held day jobs, mainly with railway companies and in insurance offices, and so teaching would regularly be scheduled for evenings (even, sometimes, for Sundays): see R. Dahrendorf, LSE: A History of the London School of Economics and Political Science 1895-1995 (Oxford: Oxford University Press, 1995) 88. 
unions, the limits of industrial coercion, and the legality of picketing. ${ }^{15}$ LSE calendars show that Wright lectured this course every year until and including 1915-16. ${ }^{16}$

He was unlikely to have missed the fee, but probably appreciated the diary space, when he ceased lecturing at the LSE. Being in his mid-forties by 1914, he was too old for enlistment and so entitled to remain at the Bar. It was around this time that work began to flood in. From 1904 to the end of 1915, Wright is listed as counsel in 42 reported cases from the High Court, King's Bench Division, Chancery, the Court of Appeal, Privy Council and Probate, Divorce and Admiralty Division. 18 of these cases were reported in 1915 alone. From 1916 until his appointment as a judge of the King's Bench Division in May 1925, he appeared as counsel in over 800 reported cases. Most of these later cases appear in the Lloyd's List Law Reports and are decisions of the specialist commercial court. The regular business, including the regular commercial business, of the courts had declined with the War, but Wright carved out a niche for himself as an expert in war-time commerce problems, particularly prize jurisdiction (the regular seizure of ships and their cargo, primarily as a result of the strict enforcement of the naval blockade against Germany, generated a considerable amount of prize court litigation) and litigation on contracts which the War made impossible to perform. Wright's usual argument was that such contracts should be declared void if the parties, had they been able to foresee what transpired, would not have gone ahead with the contract on the same terms..$^{17}$ In later years it would become clear that this is what he believed. ${ }^{18}$

By the end of World War I, Wright was certainly no longer an impecunious barrister. Indeed, in July 1917 he would take silk. The secret of his success, it seems, was that he belonged to Scrutton's chambers. Scrutton's 'peasant-boorish' behaviour may have 'verge[d] on the awful', Karl Llewellyn recalled, but he was 'a matchless commercial lawyer'19 with a particular aptitude for seeing the difference between law and social practice - as when, in commercial matters, legal rules proved ineffective because insufficiently sensitive to mercantile norms. ${ }^{20}$ Scrutton's book on merchant shipping contracts became a standard commercial

15 LSE Calendar 1903-04, 81. On Wright's teaching, see Ross Cranston, 'Praising the Professors: Commercial Law and the LSE', in R. Rawlings (ed), Law, Society and Economy: Centenary Essays for the London School of Economics and Political Science 1895-1995 (Oxford: Clarendon Press, 1997) 109-130, 113.

16 In 1915-16 he lectured the course jointly, and in 1916 the lectures were taken over by another Inner Temple barrister, C. T. Le Quesne.

17 See, e.g., Admiral Shipping Co. v Weidner, Hopkins \& Co. [1916] 1 K.B. 429. He did not always argue thus: see Arnhold Karberg \& Co. v Blythe, Green, Jourdain \& Co. [1916] 1 K.B. 495.

18 See Lord Wright, Some Developments in Commercial Law in the Present Century (Birmingham: Holdsworth Club, 1935) 4; Denny, Mott \& Dickson Ltd v James B. Fraser \& Co. [1944] A.C. 265, 275 (H.L.).

${ }^{19}$ K. N. Llewellyn, 'On Warranty of Quality, and Society' (1936) 36 Columbia L. Rev. 699, 699, 700.

20 See ibid 707-708; also Hillas v Arcos (1931) 40 Ll. L. Rep. 307, 311 per Scrutton L. J. ('I am afraid I remain quite impenitent. I think I was right and that nine out of ten business men would agree with me. But of course I recognise that I am bound as a Judge to follow the principles laid down by the House of Lords. But I regret that in many commercial matters the English law and the practice of commercial men are getting wider apart, with the result that commercial business is leaving the Courts and is being decided by commercial arbitrators with infrequent reference to the Courts'). 
law reference text, ${ }^{21}$ and coincided with the creation of the specialist commercial court. It is hardly surprising that Scrutton remembered this court with fondness: 22 for many years, he was among its busiest practitioners. His expertise as a copyright lawyer - he had published a textbook on the subject in $1883^{23}$ - meant that he was in demand in Chancery as well, and as his case-load increased so too did the amount of work that trickled down to Wright. Indeed for Wright, it seems, there was a very quick shift from famine to feast: his income from the Bar reputedly increased ten-fold - from $£, 300$ to $£, 3,000$ - within a year. ${ }^{24}$

Eventually Wright came to feel overworked as a barrister, and the change of pace which came with his appointment as a judge of the King's Bench Division apparently improved his temperament. ${ }^{25} \mathrm{He}$ may have been remembered as the worst-mannered man at the Bar but - Laski's punch-line - he had 'become the kindest judge on the bench'. ${ }^{26}$ Certainly the quality of his judicial work did not go unnoticed. He presided over the famous trial of Lord Kylsant, who, in his capacity as a company chairman, had issued a prospectus which, being economical with the truth, deceived prospective and actual shareholders regarding his company's real financial position. Wright's ruling (that intending to create a false impression by providing a document which deliberately omits important facts is as much a misdemeanour as is issuing a deliberate falsehood) was affirmed on appeal, ${ }^{27}$ though what created a lasting impression was not the fact that he had presided over what the Court of Criminal Appeal considered the right decision but that he had managed to sum up clearly an inordinately technical and complicated case which must have been difficult to put to a jury. ${ }^{28}$

The case for which Wright is best remembered as a trial judge is one in which his judgment did not prevail. In Lever Bros. $\mathrm{v}$ Bell, the defendants, having surrendered their position as managers of the plaintiff company in return for golden handshakes, were discovered by the company to have committed a breach of contract which would have justified summary dismissal without compensation. The plaintiff would have taken this action had it known of the defendants' breach

21 T. E. Scrutton, The Contract of Affreightment as Expressed in Charter Parties and Bills of Lading (London: Clowes, 1886).

22 'I think it is one of the most satisfactory systems which has yet been introduced'. T. E. Scrutton, 'The Work of the Commercial Courts' (1921) 1 C.L.J. 6, 18.

23 T. E. Scrutton, The Laws of Copyright (London: Murray, 1883).

24 Goodhart, $\mathrm{n} 7$ above, 430.

25 See Anon, 'Lord Wright: Former Lord of Appeal'; Lord Wright to Charles C. Burligham, 6 July 1925, in Charles Culp Burlingham Papers, Harvard Law School Library, Special Collections, box 19, folder 1915 ('It is indeed a change from the constant work at the Bar').

${ }^{26}$ Laski to Holmes, 20 July 1925, in Holmes-Laski Letters, I, n 9 above, 768.

${ }^{27} \mathrm{R}$ v Kylsant [1932] 1 K.B. 442.

28 See R v Kylsant, 444; also Patrick Devlin, in M. T. \& A. Devlin (eds), Taken at the Flood (East Harling: Taverner, 1996) 136-137 ('It was not an easy case to put before a jury. Apart from the fact that it all had to be conducted in the language of balance sheets ... the case did not raise the clear and simple commonsense point in which a jury is naturally in its element.... Mr Justice Wright, an experienced commercial judge, tried the case. Today cases of serious fraud are expected to last for months. The trial was set down to begin on 20 July allowing only nine working days before the end of term. The trial was concluded on 30 July, the summing up took four hours and the jury took three hours to consider their verdict. They found Lord Kylsant guilty and he was sentenced to one year's imprisonment'). 
at the time compensation for service was being negotiated. The defendants, in turn, had not fraudulently concealed the breach and appeared to be unaware that their having committed it would - had the plaintiff known of it - have affected their entitlement to their payoffs. Wright held that the service agreements were void, and that the compensation should therefore be repaid to the plaintiffs, because both parties were mistaken as to the true nature of their relationship and their respective legal rights. ${ }^{29}$

The Court of Appeal affirmed his judgment, but the House of Lords reversed it by three to two, holding that there was mutual mistake but only regarding the 'quality' of the agreement between the parties as opposed to its existence. Mutual mistake as to quality should only be treated as fundamental, and therefore sufficient to negate a contract, Lord Atkin observed, if the mistake is one 'as to the existence of some quality which makes the thing without the quality essentially different from the thing as it was believed to be. ${ }^{30}$ If $A$ buys a painting from $B$ and both are mistaken as to its true value, $A$, on discovering that he has paid above the odds, cannot have the contract invalidated on the ground that he would never have entered into the bargain had he known the true quality of the painting. Likewise, the plaintiff company in Bell could not have a service agreement voided for mistake because it had become clear (though not because of anything that had been concealed by the defendants) that the agreement could have been terminated for breach of duty, without compensation.

Wright remained, as Arthur Goodhart claims, unrepentant despite having his judgment reversed. ${ }^{31}$ But to Goodhart's comment that the directors retaining substantial compensation awards notwithstanding breach of their service agreements 'seem[ed] to show an inelastic application of the concept of mistake'32 it should be added that Wright himself did not argue as much. The House of Lords' decision was explicable, Wright claimed, as a 'forthright and uncompromising assertion of the principle that sanctity of contract is the governing motive only to be overridden by the strongest possible counterbalancing circumstances, such that they can be treated as of the substance of the contract.'33 This explanation tallies with what Lord Atkin argued. The plaintiffs had sought a termination of the defendants' contracts and had got what they had bargained for. Of course, the defendants had been 'unfaithful in some of their work' yet 'retain[ed] large compensation which some will think they do not deserve.'

Nevertheless it is of greater importance that well established principles of contract should be maintained than that a particular hardship should be

${ }^{29}$ See Lever Bros. v Bell [1931] 1 K.B. 557, 569.

30 Bell v Lever Bros. [1932] A.C. 161, 218.

31 See Lord Wright, 'Pollock on Contracts' (1943) 59 L.Q.R. 122, 127; Goodhart, n 7 above, 432

32 Goodhart, $\mathrm{n} 7$ above, 432.

33 Lord Wright, 'Lord Atkin of Aberdovey, 1867-1944' (1946) 32 P.B.A. 307, 322 (hereafter 'Atkin' (P.B.A.)). 
redressed; and I see no way of giving relief to the plaintiffs in the present circumstances except by confiding to the Courts loose powers of introducing terms into contracts which would only serve to introduce doubt and confusion where certainty is essential. ${ }^{34}$

Wright never openly lamented the House of Lords' decision, but he did rather pointedly note that one of the great contracts scholars of his day, Williston, disapproved of it. ${ }^{35}$ One of the reasons his judgment remains historically significant is that others who were freer than were English judges to criticize House of Lords' decision were clearly on the side of the High Court and the Court of Appeal. ${ }^{36}$ It seems that Wright himself did not come to the judgment easily (the fashionable American realist claim of this period, that judges decide by following their hunches, ${ }^{37}$ certainly does no justice to it), for at the outset he was apparently not convinced that Bell was an instance in which mutual mistake could be established. At trial, counsel for the plaintiffs had only argued for rescission on grounds of mistake after becoming convinced that proving misrepresentation that the defendants' actions constituting breach of duty must have been in their minds when they negotiated their service agreements - was too tall an order. Wright had apparently considered the plea of mistake odd, and seems to have gone against his own instincts - and certainly went against the wishes of counsel for the defendants - in allowing questions on this point to go to the jury. ${ }^{38}$

By the early 1930s, Wright had the profile of a Lord of Appeal in waiting. By that point, furthermore, there had been a partial but significant changing of the guard in the House of Lords. Lord Atkinson retired in 1928, Lords Carson and Shaw in 1929, Lord Sumner in 1930 and Lord Dunedin in 1932. Sumner and, to a lesser degree, Dunedin were notable mainly for their successes as lawyers before being appointed to the House of Lords. ${ }^{39}$ But the others were more typical Lords of Appeal of this era, having been chosen primarily for their political achievements rather than their professional successes. Atkinson had an unspectacular career as barrister and law officer in Ireland before being appointed as 'a loyal Conservative'

\footnotetext{
34 Bell v Lever Bros., 229.

35 See Wright, LEA 214-217.

${ }^{36}$ See, e.g., H.A.E., 'Contract - Mistake in Formation' (1932) 4 C.L.J. 370; R.S.T.C., note (1932) 48 L.Q.R. 151; H.C.G., 'Bell v. Lever Brothers Ltd' (1932) 48 L.Q.R. 148; R. Champness, Mistake in the Law of Contract (London: Stevens \& Sons, 1933) 20-26; P.A. Landon, 'Bell v. Lever' (1935) 51 L.Q.R. 650; P.A. Landon, 'Bell v. Lever Bros.' (1936) 52 L.Q.R. 478. There were, none the less, compelling voices on the other side, too: see, e.g., F. H. Lawson, 'Error in Substantia' (1936) 52 L.Q.R. 79; T. H. Tylor, 'Bell v. Lever Bros.' (1936) 52 L.Q.R. 27; C. J. Hamson, 'Bell v. Lever Bros.' (1937) 53 L.Q.R. 118; and especially H.W.R. Wade, 'Consensus Mistake and Impossibility in Contract' (1941) 7 C.L.J. 361, 367.

${ }^{37}$ See J.C. Hutcheson, Jr., 'The Judgement Intuitive: The Function of the "Hunch" in the Judicial Decision' (1929) 14 Cornell L.Q. 274, 278.

38 See C. MacMillan, 'How Temptation Led to Mistake: An Explanation of Bell v. Lever Brothers, Ltd.' (2003) 119 L.Q.R. 625, 645-646.

39 Sumner had been a successful commercial barrister and sat in both the King's Bench Division (190912) and the Court of Appeal (1912-13). Dunedin had briefly been a Conservative MP and Secretary of State for Scotland, but was also President of the Court of Session for eight years (1905-13).
} 
to replace Lord Lindley in $1905.4^{40}$ Carson was principally a Conservative politician rather than a judge. ${ }^{41}$ Shaw's appointment met with opposition on the basis that he was 'not a lawyer of stature' but someone who 'simply wished to "cut a figure" in the House of Lords. ${ }^{42}$ Between 1912 and 1915 the then Lord Chancellor, Lord Haldane, had broken somewhat with tradition by seeking to appoint professional judges as Lords of Appeal. The initiative was taken up by some of his successors, particularly by Lord Sankey, who became Lord Chancellor in 1929. Dunedin, by the time of his retirement, had acquired a reputation for, as Wright would put it a decade later, applying law ... touched ... by common sense. ${ }^{43}$ Wright, as a judge, was similarly inclined towards 'the retention of common sense as a sort of life line' in his legal arguments, ${ }^{44}$ and in due course would demonstrate himself to be a liberal progressive somewhat in the mould of Shaw. By the time that Dunedin retired, furthermore, Wright had demonstrated his dedication to judicial office; he had the 'professional' profile that Sankey sought in his appointees to the House of Lords.

On the recommendation of Sankey, Wright was promoted directly from the King's Bench Division to the House of Lords, bypassing the Court of Appeal, in April 1932. There was, however, a twist to the tale. In 1935, Lord Hanworth resigned as Master of the Rolls (the presiding judge of the Court of Appeal) owing to ill health. Stanley Baldwin, who in June had swapped posts with Ramsay MacDonald to become Prime Minister for a third time, had difficulty finding a suitable replacement for Hanworth. Wright was asked to step into Hanworth's shoes and he did so in October, apparently on the understanding that the move was temporary and that he would be reinstated to the House of Lords as soon as a new vacancy arose among the Lords of Appeal. Not only did presiding over the Court of Appeal prove taxing for Wright - by this point he was in his sixties and reputedly rather frail - but, to his frustration, a vacancy enabling him to return to the House of Lords did not arise until April 1937.45

Wright remained as a Lord of Appeal until his retirement a decade later. While the common characterization of him - as a progressive judge who was interested in juristic speculation about law, ${ }^{46}$ and who was willing to entertain new

40 R. Stevens, Law and Politics: The House of Lords as a Judicial Body, 1800-1976 (Chapel Hill, NC: University of North Carolina Press, 1978) 259

41 See ibid 266-268.

42 R. F. V. Heuston, Lives of the Lord Chancellors, 1885-1940 (Oxford: Clarendon Press, 1987) 149.

${ }^{43}$ [Lord Wright], 'Lord Dunedin' (1942) 92 Law Journal 317, 317.

44 B. L. Shientag, Moulders of Legal Thought (Port Washington, NY: Kennikat Press, 1968 [1943]) 246. See also Lord Wright, 'An Extra Judicial Confession', unpublished typescript, n.d., 6pp., in Arthur Lehman Goodhart papers, Bodleian Library (Special Collections), Oxford, MS Eng. c. 3113 ('[L]aw should, as far as possible, be thought of in broad common sense terms and according with what the reasonable man would wish it to be')

45 The wait seemed to spark his sense of vanity as well as frustrate him: see Lord Wright to A. L. Goodhart, 12 March 1937, in Goodhart papers, Bodleian (Special Collections), MS Eng. c. 2891 ('I am a rather transient [Master of the] Rolls and hope soon to be back permanently to the Lords and I am better known especially abroad as Lord Wright. People would say who is the Master of the Rolls?').

46 As evidence see, e.g., LEA 174-185, 327-328, 402-403. 
ideas and challenge orthodoxies ${ }^{47}$ - is certainly not inaccurate, it fails to capture something about the man. Wright was one of a small number of mid-twentieth century law lords (Atkin, MacDermott and Radcliffe would also fall into this category) who was more serious, rigorous and successful in his efforts to reflect on the nature and function of law than were many of his contemporaries in England whose job it was to try to understand law theoretically - the generation of jurisprudents, that is, which preceded Hart and which made no sizeable advance on the work of Austin.

My decision to deal with Wright's efforts in this regard under the heading of 'innovative traditionalism' needs to be treated with caution. The label, as was intimated earlier, does not distinguish him from other judges. Indeed, given that there is probably a traditionalist and an innovator in everyone, labelling him thus might seem trite. It is the nature of Wright's innovative traditionalism, I am arguing, that marks him out. To understand Wright, and his significance, as a judge it is important to appreciate that he explained with originality and analytical sophistication - which is not to say that his explanations were always accepted, or that his analyses from one area of law to another could always be reconciled - how it is that judges are able to make law while upholding established legal conventions and authorities. The most obvious place to turn, in order to begin to get some sense of Wright's particular skill as an innovative traditionalist, is to his views on the judicial handling of precedents, public policy arguments and statutes.

\section{THE JUDGE AND THE LAW}

Wright knew how to play the part of the progressive-minded judge. He liked to insist that the law 'must be regarded as a living organism', 48 and he shared the then contemporary American juristic disdain for mechanical jurisprudence ${ }^{49}$ and enthusiasm for the idea of law at the service of society. ${ }^{50}$ But he was not inclined to explore such sentiments carefully. Indeed, anyone who inspects his judicial work closely might be forgiven for assuming his progressivism to be superficial, for he would sometimes sidestep bold conclusions and his predilection for tradition could get the better of him. He could be as dogged a rule-formalist as any judge. ${ }^{51} \mathrm{He}$ believed in the omniscience of Parliament and the separation of

\footnotetext{
${ }^{47}$ See, e.g., Lord Denning, 'The Way of an Iconoclast' (1960) 3 Sydney L. Rev. 209, 213.

${ }^{48}$ LEA 344; also 328, 385, 389, 395, 399, 401, 412.

${ }^{49}$ See, e.g., Lord Wright, n 44 above,, 1 ('I have always rejected the merely authoritative criterion of law, by which I mean the merely formal or mechanical test for construing statutes or applying legal rules...'). 50 See, e.g., LEA xxi, 348.

${ }^{51}$ See, e.g., IRC v Duke of Westminster [1936] A.C. 1, 30 ('On the footing that the deed is genuine, I do not see any possibility of going behind what appears on the face of the document, or qualifying its effect by documents dehors the deed and in no way embodied in it, or regarding the payments as other than annual payments, as it is admitted that ex facie they are').
} 
powers, ${ }^{52}$ and he was out of step with emerging legal opinion in the 1930s and '40s regarding the elasticity of the established rights of appeal against decisions of statutory bodies..$^{53}$ In Privy Council decisions of the 1930s - this was the era when the Judicial Committee would offer a single judgment instead of separate opinions - there is a suspicion that he avoided rocking the boat. He delivered the Council's judgment in James v Commonwealth of Australia in 1936, observing that the words 'absolutely free' in s. 92 of the Australian Constitution of 1901 (which provided that 'trade, commerce, and intercourse among the States ... shall be absolutely free') denote not absolute freedom but only freedom of goods passing into or out of States, meaning that legislation prohibiting inter-State trade had to be constitutionally invalid. ${ }^{54}$ In 1954, however, he 'urge[d] a complete reconsideration of s.92', having become convinced that "absolutely" ... means what it says, and ... cannot receive any true effect consistent with any ordinary principle of construction unless it indicates that the freedom, whatever it is which is being established, has no limitations or qualifications at all'.55 Attorney-General for Canada v Attorney-General for Ontario, decided in 1937, concerned s. 92 of the British North America Act 1897, which assigned matters of 'property and civil rights' exclusively to the legislatures of the provinces. Because these matters were assigned thus, Lord Atkin (delivering the Privy Council's judgment) argued, they could not be the responsibility of the dominion, which meant that the dominion was not entitled to enact legislation implementing the labour provision in the conventions of the International Labour Organization of the League of Nations (as established under the Labour Part of the Treaty of Versailles 1919), and so had no authority to enact minimum wage legislation. ${ }^{56}$ In 1955, in an obituary for the judge whose Canadian Supreme Court decision had been overruled, Wright, who had sat in this case, made it clear that he thought 'the Privy Council, speaking through Lord Atkin,' had interpreted the British North America Act incorrectly. ${ }^{57}$ Perhaps this was Wright's confession that he had dissented, ${ }^{58}$ though the Council's refusal before 1966 to publish its dissenting opinions makes it impossible to be sure. ${ }^{59}$ In both of these Privy Council cases, there are reasons to think that Wright, perhaps to his later regret, may have been timorous rather than bold.

\footnotetext{
52 See, e.g., The Arantzazu Mendi [1939] A.C. 256, 267-268; National Anti-vivisection Society v IRC [1948] A.C. 31, 41-52.

53 For Wright, there could be no right of appeal beyond certiorari to have a decision quashed or mandamus to compel a re-hearing: see GMC v Spackman [1943] A.C. 627, 640.

${ }^{54}$ James v Commonwealth of Australia [1936] A.C. 578, 629-630.

${ }^{55}$ Lord Wright, 'Section 92 - A Problem Piece' (1954) 1 Sydney L. Rev. 145, 147 and 157.

56 Attorney-General for Canada v Attorney-General for Ontario [1937] A.C. 326. In essence the Privy Council, in determining that the treaty-ratifying capacity of federal government was restricted by virtue of s. 92, was imposing on Canada its own version of the United States Senate's unsuccessful Bricker Amendment of the 1950s.

${ }^{57}$ Lord Wright, 'Rt. Hon. Sir Lyman Poore Duff, G.M.C.G.: 1865-1955’ (1955) 33 Can. Bar Rev. 1122, 1126-1127.

${ }^{58}$ B. J. MacKinnon, Letter to the Editor (1956) 34 Can. Bar Rev. 115, 116-117.

${ }^{59}$ F. R. Scott, Letter to the Editor (1956) 34 Can. Bar Rev. 114, 115.
} 
It would be a mistake, however, to conclude on the basis of these cases that Wright's progressive attitude was superficial. That it had some substance to it is particularly evident from his reflective and, compared with many of his English judicial contemporaries, somewhat unconventional account of how judges handle precedents.

\section{Precedent}

Do not underestimate the importance of precedent, Wright insisted. A precedent can 'embody a juristic principle of permanent value, such as trespass, deceit, defamation or nuisance'. ${ }^{60}$ Without precedent 'there could be no certainty in law and people could not regulate their conduct to comply with law.' ${ }^{91}$ '[T] he respect for precedents is not only natural and intelligible, but is deep-rooted in the English legal tradition'62 - indeed, the practice of precedent-following is so deeply impressed in the mind of an English judge that he finds it hard to approach any problem except by first turning to the authorities'. ${ }^{63}$

But just what it means for a judge to treat a precedent as authority, Wright believed, is something that even judges themselves occasionally misunderstand. 'When we speak, as we often do, of law being bound hard and fast by precedent, we are apt to forget that precedents may have the opposite effect and lead to advance in the law', ${ }^{64}$ and that 'from the earliest times judges have really made laws, that is legislated, even though they pretended to be declaring law which already existed. ${ }^{65}$ Although formal justice should not be disparaged- a basic virtue of law, Wright insisted, is that it 'upholds the equality of all men, it impartially regards the proud and the lowly" 66 - the doctrine of precedent is intriguing not because it instantiates the principle that like cases ought to be treated alike but because it reconciles the continuity of the common law with the fact of its perpetual change. ${ }^{67}$

Wright sought to explain how precedent works so as to enable the common law to embody both of these characteristics. The doctrine of stare decisis is 'useful in its proper place', but it 'must not become a fetish'68; for the 'underlying purpose' of precedent-following is 'to seek and ensure justice' 69 - the 'judge must ... know his cases and how to use them, and how to reconcile with adherence to precedent

\footnotetext{
${ }^{60}$ LEA 126.

61 LEA 192.

${ }^{62}$ Lord Wright, 'Precedents' (1943) 8 C.L.J. 118, 144.

${ }^{63} \mathrm{LEA}$ 341. Wright considered it a matter for 'regret' that the citation of non-English common-law authorities - as persuasive rather than as binding precedents, one assumes - had, by the late 1930s, 'almost completely ceased in England.' LEA 205. It is also noticeable that he would cite the works of living authors in court.

64 LEA 204.

65 LEA 193.

66 LEA 409.

${ }^{67}$ See $L E A$ xvi.

68 Wright, n 44 above, 2-3.

${ }^{69}$ LEA 25; see also 344.
} 
such innovations as justice requires ${ }^{70}$ - which means courts should treat precedents not as 'definite rules' to be 'rigidly applied' but as 'prima facie presumptions' which 'may admit exceptions'. ${ }^{71}$ Inevitably, ' $[\mathrm{t}]$ here is a large scope for what is called judge-made law': ${ }^{72}$ the 'elasticity in the authorities ${ }^{73}$ - not so much a matter of 'relevant rules' being 'uncertain' as there being uncertainty as to 'what is the right rule to apply'74- often puts a judge, with an eye on 'the requirements of justice', in the position of being 'compelled ... to modify or vary or innovate on the law, creating new or partially new principles, but keeping, actually or ostensibly, within or close to the decided cases. ${ }^{75}$

This compulsion will sometimes require that precedents be overruled and even, one would think, that a court of final appeal occasionally overrule precedents of its own. Wright must have recognized the last scenario to be the logical conclusion to his argument but - being of a generation that pre-dated the House of Lords' decision in 1966 to treat its own precedents 'as normally binding' but to 'depart from' them 'when it appears right to do so'76 - he declined to say as much. ${ }^{77}$ Although there is reason to think that he would have welcomed the prospect of the House of Lords overruling its own precedents, ${ }^{78}$ he regarded such an action to be, according to the conventions of his era, one of the 'definite limits beyond which no judge would go'79 (strictly speaking, he claimed, 'a decision of the House of Lords' could 'be changed [i.e., reversed] only ... by an act of the Legislature'80). He correctly predicted, furthermore, that if the House of Lords did ever alter its practice on precedent-following, it would rarely overrule itself. ${ }^{81}$

As regards distinguishing, however, he was decidedly more sanguine. Cases

\footnotetext{
${ }^{70}$ LEA 388.

${ }^{71}$ LEA $167-168$.

${ }^{72}$ LEA 190; and see also Wright, 'Atkin' (P.B.A.) 313); Wright, $\mathrm{n} 44$ above, 1 ('In important cases the judge, especially the judge of a Court of ultimate appeal, is making new law, he is a legislator; his decision is an act of the will.... He is a pragmatist.... His task is to examine authorities, because according to the Common Law ideal he must as far as possible achieve continuity, but the continuity he must aim at is not merely verbal continuity but continuity of ideas').

73 LEA 341.

${ }^{74}$ LEA 343; see also xx ('the judge nearly always has some degree of choice').

75 LEA 342

76 Practice Statement (Judicial Precedent) [1966] 1 W.L.R. 1234.

${ }^{77}$ Even the prospect of overruling lower courts' established precedents is one which, certainly during his early years as a Lord of Appeal, he felt the House of Lords had to approach with caution: see Admiralty Commissioners v Valverda [1938] A.C. 173. By the end of his judicial career his view on this matter seemed somewhat more relaxed: see National Anti-vivisection Society v IRC, 46 ('One of the most important aspects of the judicial functions of this House is to harmonize or correct the decisions of the lower courts'). As for when Wright thought the power to overrule lowers courts should be exercised, see Lissenden $\mathrm{v}$ Bosch [1940] A.C. 412, 432 ('[T] his House has the duty to reconsider [a precedent] when at last it is brought before it and to set it aside if it is seen to be contrary to justice and convenience'); Wright, n 62 above, 136-138.

78 See Wright, n 62 above, 145 - 'I feel that there is greater public inconvenience in perpetuating an erroneous judicial opinion, than the inconvenience to the Court of having a question, disposed of in an earlier case, re-opened' - though note that the court to which Wright is referring here is the Court of Appeal, not the House of Lords.

${ }^{79} \mathrm{LE} A \mathrm{xx}$

${ }^{80}$ Wright, n 62 above, 120; see also Radcliffe v Ribble Motor Services, Ltd. [1939] A.C. 215, 246-247.

${ }^{81}$ Wright, n 62 above, 144.
} 
must be understood 'not as dead precedents' 82 but as 'decisions' which 'seem to drop out of sight and become superseded' 83 as judges 'distinguish] the case[s] before [them] from the authority of the earlier cases cited as binding'. ${ }^{84} \mathrm{~A}$ judge may find a case which is on all fours with 'the case before him, but it will more generally happen that he will be able to select a case or cases more or less near, which take him so far towards his decision and then leave him to finish the task of judgment by his own resources. ${ }^{95}$ Since a 'decision is an authority only for what it actually decides' ${ }^{86}$ and since a judge will 'instinctively know what is the legal way ... of selecting the relevant facts's7 and so should be 'able to see where exactly the cases cited differ from that present to him', 88 it will often be possible for a court, 'without any breach of authority or contradiction in principle', ${ }^{89}$ to demonstrate that the case before it today requires a ruling based on a set of facts different - if only subtly different - from the facts which were deemed to be operative in the cited precedents. So it is that the pace at which the common law changes is essentially glacier-like..$^{0}$ And so it is that "judges ... evolve the law by experience and experiment, profiting at each stage by the work of their predecessors. ${ }^{91}$

It was in an area of law dominated by statutes, interestingly enough, that Wright was able to put his own talent for distinguishing to notable effect. There 'seems now to be established', he wrote in the mid-1930s, a 'general rule of vicarious responsibility' to the effect that 'a person causing something to be done, the doing of which casts on him a duty, cannot escape from the responsibility ... by delegating it to a contractor' unless the party in receipt of the delegated service has notice that there is 'some limitation' on liability attaching to the principal. ${ }^{92}$ If limits are not placed on the extent to which employers are held liable for their principals' actions, however, an employee might recover against an employer for another employee's negligence. The position established at common law in the mid-nineteenth century was that an employee, in undertaking to perform a service for the employer, was presumed to accept responsibility for risks of injury caused by fellow employees..$^{93}$ So it was that employers sought to escape liability for injuries sustained by employees while performing services by mounting the defence that responsibility for such injuries lay with fellow employees because they either caused the harm or were employed to oversee the activity which led to the harm. These 'fellow employees' did not necessarily work with the victim; they may

82 LEA 395.

${ }^{83}$ LEA 400.

${ }^{84}$ LEA 399.

${ }^{85}$ Wright, n 62 above, 139.

${ }^{86}$ LEA 399

${ }^{87}$ LEA 408.

${ }^{88} L E A$ xviii.

${ }^{89}$ LEA 204.

${ }^{90}$ See $L E A$ xvi.

${ }^{91}$ LEA 341.

${ }^{2}$ LEA 262, 143, 142, 262; see also 400-401.

93 See Priestley v Fowler (1837) 3 M \& W 1; Hutchison v The York, Newcastle Railway (1850) 5 Exch. 351; Wigmore v Jay (1850) 5 Exch. 354. 
have been fellow employees only in the sense that they and the victim were contracted to provide a particular service for the employer. ${ }^{94}$

This doctrine of 'common employment' was emasculated somewhat by legislation of the 1880s requiring employers to compensate personal injury to workers caused 'by accident arising out of and in the course of employment. ${ }^{9} 95$ The doctrine continued to apply, none the less, where employers argued exemption from vicarious liability on the basis that injury was caused by the negligence of another employee. The doctrine remains 'well-established,' Wright observed in 1937, though he immediately added that it is 'illogical', and 'certainly one not to be extended'. ${ }^{96}$ The rationale for the doctrine is in fact straightforward: it prevents the possibility of employers being found liable for injury suffered by an employee owing to the action of a fellow employee - action over which an employer is unlikely to have any control. This is not to claim that the level of protection the doctrine afforded to employees was satisfactory. Liability could attach to the supervisor who delegated responsibility for an action which caused injury to another employee but it was unlikely to attach to the employer who delegated the responsibility of delegation to the supervisor; so long as an employer had exercised due care in selecting competent employees - this was the conclusion reached by the Court of Appeal in the early $1930 \mathrm{~s}^{97}$ - he had done all he was bound to do.

Wright argued that the 'opinions and decisions of [the House of Lords] and the Court of Appeal over a long period of years ${ }^{98}$ in fact pointed to a different conclusion. An examination of the leading cases on common employment showed 'that the doctrine ... has always distinguished between the employer's duty to the employee and the fellow servant's duty to the employee'. ${ }^{99}$ The fact that 'the workman takes the risk of his fellow workman's negligence' does not mean that he 'take[s] the risk of his master's negligence. ${ }^{100}$ Indeed, the House of Lords had long taken the view that 'the employer's obligation ... is personal to the employer': an employer cannot absolve himself from the duty to provide employees with a reasonably safe place of work simply by appointing a competent person to perform the duty for him. ${ }^{101}$ The mistake of the Court of Appeal in its offending decisions of the early 1930s was to conclude that an employer could be exempt from his own 'province of duty' by virtue of 'a number of cases in which' an employee successfully alleged not the negligence of his employer but 'the negligence $\ldots$ of those who were fellow servants'. ${ }^{102}$

The purpose of distinguishing in this instance was to put the correct line of

${ }^{94}$ See Wilson v Merry (1868) 1 L.R. Sc. \& Div. 326.

95 Workmen's Compensation Act 1897, s. 1(1). See also Wright, LEA 362.

96 Wilsons \& Clyde Coal Co. v English [1938] A.C. 57, 79 (decided 1937).

${ }^{97}$ See Fanton v Denville [1932] 2 K.B. 309; Rudd v Elder Dempster \& Co. [1933] 1 K.B. 566.

98 Wilsons \& Clyde $\mathrm{v}$ English, 78.

99 ibid 80.

100 ibid 82.

101 ibid 80; and see also Lochgelly Iron \& Coal Co. v M'Mullan [1934] A.C. 1, 21-22, 30-31.

102 Wilson's \& Clyde v English, 82-83. 
authority back on track after the Court of Appeal had derailed it. That Wright truly believed the Court of Appeal's sleight of hand was quite so egregious seems doubtful. Those opinions and decisions in which the Court of Appeal and the House of Lords had spoken of the personal, non-delegable duty of the employer were not ignored but 'put aside' in the decisions which Wright sought to discredit; 'these observations ... [i]t was said ... were obiter dicta, which may in one sense be true'. ${ }^{103}$ That he should have tried so hard to nullify the doctrine of common employment is probably attributable to the fact that he considered it to depend on something which, as we know from his rejection of implied contract analysis, he thoroughly deplored: the legal fiction. '[T] he doctrine', he noted in Wilsons \& Clyde Coal Co. v English in 1937, is explained on the ground that the employee by his contract of employment agrees with his employer to assume the risk of his fellow servant's negligence. The principle is stated, with little regard to reality or to modern economics or industrial conditions, to be that this particular risk is included in the agreed remuneration.' 104 The December case notes in the first volume of the Modern Law Review, published in the same year, concerned the state of common employment doctrine in the light of Wilsons \& Clyde. William A. Robson, then Professor of Public Administration at the London School of Economics, echoed Wright and opined 'that the Lord Chancellor might well invite the Committee on Law Revision to report to him on the subject.'105 Joseph Gold, a member of the journal's editorial committee, dismissed the doctrine with language worthy of many an American legal realist:

It must be clear to all lawyers by now that this [doctrine] is a feeble fiction adopted to clothe with legal argument a balancing of interests already struck by the judges in favour of the employer. It is a conception derived from that period when a few servants worked with simple tools under the personal supervision of their employer. The workman who to-day engages in a huge industrial undertaking is almost completely unaware of the nature and number of the risks to which he is subjected. It is absurd to say that he voluntarily assumed these risks. It has been repeatedly said that since he enters the employment of his own volition he must be taken to have impliedly assumed the risks. This, too, is a relic of the period when the supply of labour did not as now far exceed demand. A workman has little freedom of choice to-day when there are one to two million men from whom his employer may choose a substitute. Nevertheless, the fiction of voluntary assumption of risk persists .... ${ }^{106}$

\footnotetext{
103 ibid 82.

104 ibid 80.

105 W.A. Robson, 'Common Employment' (1937) 1 M.L.R. 224, 225.

106 J. Gold, 'Common Employment' (1937) 1 M.L.R. 225, 228. Cf., e.g., M. R. Cohen, 'The Basis of Contract' (1933) 46 Harv. L. Rev. 553, 560, also 569 ('There is, in fact, no real bargaining between the modern large employer ... and its individual employees. The working-man has no real power to negotiate or confer with the corporation as to the terms under which he will agree to work. He either decides to work under the conditions and schedule of wages fixed by the employer or else he is out of a job'); Felix
} 
Robson's suggestion was pointed: Wright had been a member of the Law Revision Committee since its inception in 1934, and by 1937 he was its chairman. The Committee was, however, disbanded in 1939, and between June of that year and December 1936 it had published four reports, so it is unlikely there was ever an opportunity for the Lord Chancellor to act on Robson's suggestion, even if he was aware of it. ${ }^{107}$ Although Wright sympathized with and regularly echoed the sentiment expressed by Gold, ${ }^{108}$ he was in no doubt that only Parliament could put an end to the defence of common employment. ${ }^{109}$ However he could, indeed he did, restrict the availability of the defence. The notion of 'common employment' connotes commonality of enterprise, he argued in Radcliffe $\mathrm{v}$ Ribble, and so the defence 'does not apply where the injured man and the negligent employee are not engaged in the same common work or are not fellow labourers in the same work or are engaged in different departments of duty. ${ }^{110}$ The test of commonality is the contract of service: 'the fundamental principle [is] that there must be an actual contract between the employer and employee so that it may be possible from the nature and circumstances of that contract to imply, though by a fiction of law, that the employee undertook the particular risks of the negligence of his fellow employees. ${ }^{111}$ Wright's apparent endorsement of the legal fiction in this instance can be explained: common employment may be 'an arbitrary departure from the rules of the common law based on a prejudiced and one-sided notion of what was called public policy, and sanctioned by no previous authority', ${ }^{112}$ but the fact is that the doctrine is well established, and the only way in which one can sensibly explain the courts' rationale for accepting it is by invoking the legal fiction. Given that the doctrine has been accepted - this is the essence of Wright's position ${ }^{113}$ - the challenge is to rein it in as much as possible, and hope that Parliament will see (as it did in 194814) the sense in abolishing it

S. Cohen, 'The Problems of a Functional Jurisprudence' (1937) 1 M.L.R. 5, 21. This last article was written after Gold, at the behest of the Modern Law Review Editorial Committee, approached Felix Cohen to contribute to the first volume of the journal: see C. Glasser, 'Radicals and Refugees: The Foundation of the Modern Law Review and English Legal Scholarship' (1987) 50 M.L.R. 688, 701.

107 Though the Committee did find time to report on contributory negligence, a defence which Wright had advocated in his judicial speeches with much the same vigour as he had put into criticizing common employment. See Law Revision Committee, Eighth Report: Contributory Negligence, Cmd. 6032 (London: HMSO, 1939). As a result of the Committee's recommendations, Parliament enacted the Law Reform (Contributory Negligence) Act 1945. For Wright's support for the defence of contributory negligence, see Flower v Ebbw Vale Steel, Iron \& Coal Co. [1936] A.C. 206, 211-212; Caswell v Powell Duffryn Associated Collieries [1940] A.C. 152, 169-180.

${ }^{108}$ See, e.g., LEA 200-201, 398 ('The doctrine of common employment originated in the old Tory attitude to labour') 424-425; Century Insurance Co., Ltd. v Northern Ireland Road Transport Board [1942] APP. L.R. 03/04, paras. 11-20; Montreal v Montreal Locomotive Works, Ltd. [1947] 1 D.L.R. 161, para. 19 (P.C.).

${ }^{109}$ See Radcliffe $\mathrm{v}$ Ribble, 246.

110 ibid 238

111 ibid 247.

112 ibid 245

113 'The reasoning of Priestley v. Fowler, which was that the principal is not liable for harm done by his servant to another servant of his, would not, I think, be given to-day by any judge who is not bound by authority.' LEA 362

${ }^{114}$ Law Reform (Personal Injuries) Act 1948. 
altogether.

\section{Public Policy}

Wright's innovative-traditionalist approach to common employment in particular and precedent generally - that judges can legitimately move the law beyond, though not too far beyond, the authorities by which they recognize themselves to be bound - is reflected in his understanding of public policy. Not only is it 'for the Legislature, not the judges, to invent new heads of public policy', he argued, but judges are generally disinclined to usurp the legislative function because their 'outlook' is 'essentially individualist' in nature and their methods ill-suited to 'satisfy[ing] modern ideas of collectivism and social planning'. ${ }^{115}$ Certainly the first half of the twentieth century had witnessed a 'transition from individualism to ... a policy ... of ... social assistance and instruction and social regimentation', but the fact of the matter was that ' $[\mathrm{t}]$ his aspect of ... public policy' remained - and judges were essentially content for it to remain - 'outside the common law.'116

Courts sometimes will, nevertheless, have to choose between policies which conflict with one another, and sometimes will rely on public policy arguments inappropriately. Illustrative of the first instance is the Court of Appeal's decision in Beresford $\mathrm{v}$ Royal Insurance Co., in which Wright, as Master of the Rolls, reversed a judge who held that assignees seeking to claim on the life insurance policy of a man who had committed suicide while being of sane mind were entitled to do so. The judge had considered the claim legitimate because the insurance policy did not exempt payment in the event of the assured dying by his own hand while sane and because public policy requires that promises be kept. At the heart of the matter was public policy, Wright conceded, but the relevant policy was that a criminal or his representative should not be allowed to profit from crime (in this case, selfmurder). ${ }^{117}$ An example of the second instance is Fender $\mathrm{v}$ St. John-Mildmay, in which the defendant had, before divorce from his wife was finalized, promised to marry the claimant. The promise was subsequently repudiated, and the claimant, who had relied on the promise to her detriment, successfully brought an action in damages. But the defendant avoided paying damages on the ground that his promise was contrary to public policy - to treat such promises as enforceable militates against separated couples reconciling - and so he could not be bound to fulfil it. This ground was accepted both at trial and in the Court of Appeal, but not in the House of Lords. ${ }^{118}$ Wright - who, in the same month that the House decided the case, had declared that he 'fervently support[ed]' the extension of the

\footnotetext{
${ }_{115}$ LEA 250, 362, 347.

116 LEA 381.

117 See Beresford v Royal Insurance Co., Ltd [1937] 2 K.B. 197, 219. The decision was affirmed by the House of Lords: Beresford v Royal Insurance Co. [1938] A.C. 586.

118 Fender v St. John-Mildmay [1938] A.C. 1. Lords Russell and Killowen dissented.
} 
grounds for divorce under A. P. Herbert's Matrimonial Causes Act of 1937119 seemed incredulous that anybody should consider it contrary to public policy to allow a man who has not yet been granted a decree absolute to be sued for breach of promise. Of course, in Fender the marriage was still valid in the sense that it would continue until the decree absolute. 'But it is obvious that in truth and in substance there is no longer any marriage... The Court has pronounced for dissolution to take place.... If realities are to be looked at ..., the marriage is at an end, and the parties are entitled to provide for their future'. ${ }^{120}$ While enforcing the promise was, in theory, an obstacle to the husband and wife being reconciled, there was in reality little or no 'public interest in seeking to preserve, at the expense of the solid detriment of sanctioning a breach of contract, the transitory and unsubstantial form of a marriage which by the decree of the Court is practically doomed to extinction in a brief period of months. ${ }^{121}$

There is an unmistakable tone of self-assurance and certainty running throughout Wright's analyses of both precedent and public policy. Judges, he is saying, instinctively know which types of public policy they can, and which they cannot, legitimately advance, just as their legal training endows them with an understanding of both the constraints imposed and the leeway afforded by the doctrine of stare decisis. His regular depiction of judges as architects of principle tempts the superficial conclusion that he was a Dworkinian avant la lettre.122 But it is really the tradition of H.L.A. Hart which he anticipates. Hart's idea of the internal point of view is essentially that judges identify certain patterns of behaviour, such as precedent-following, as composing 'a public, common standard of correct judicial decision.'123 These patterns of behaviour are regarded as correct practices, and the judges who share these practices will more often than not consider judicial 'deviations' from them to be 'lapses'. ${ }^{24}$ Wright would have grasped the idea immediately. The authority of the common law, indeed the reason 'that law and its practitioners ... have their place in the public esteem', is attributable, he believed, to the fact that judges demonstrate respect for and commitment to shared standards of legality, to their acceptance of and willingness to defend and promote judicial independence and fairness ..., trial by jury, freedom from unlawful arrest or detention, the fairness of the criminal law, freedom of speech' and other 'root ideas' of the system.125 The analytical project undertaken in The Concept of Law is, it should be said, considerably more

119 'I fervently support his Bill. I think it will promote domestic happiness.' 105 Parl. Deb., H.L. (5 ${ }^{\text {th }}$ ser.) col. 838 (28 June 1937). Previously, adultery had been the only ground on which divorce could be granted. After the Act, cruelty, insanity and unlawful desertion for two years or more all became grounds.

${ }^{120}$ Fender v St. John-Mildmay, 46.

121 ibid 36.

122 Cf., e.g., LE $A 328$ ('The judge, exercising his historic function, is constantly enlarging the area of the law by applying old principles to new cases and by limiting and redefining existing principles in the light of new circumstances, and very occasionally he will be able to establish a new principle') with $\mathrm{R}$. Dworkin, Law's Empire (London: Fontana, 1986) 251-252, 402.

${ }^{123}$ H. L. A. Hart, The Concept of Law (Oxford: Clarendon Press, 2 ${ }^{\text {nd }}$ ed, 1994) 116.

124 ibid.

${ }^{125}$ LEA 410 
sophisticated than are Wright's speculative, hortatory reassurances that if judges behave properly then 'the public' is likely to be inspired by their example. In both instances, none the less, an argument is set out to the effect that the authority of law is attributable to judges' internalization of certain standards of legality. Wright's reliance on this argument enables him to be both innovator and traditionalist. Judges can and often should innovate - the subtle conventions of precedent and public policy, 'vital part[s] of the lawyer's equipment', ${ }^{26}$ tell them this. But because they understand these conventions they also know that there are constraints on judicial creativity, that 'to do justice' they must do 'justice according to law'. ${ }^{127}$

\section{LEGISLATION: THE WORKER AND THE LAW}

Wright approached legislation as a common lawyer in an age of statutes. The question of how statutes should be interpreted seemed to exasperate him, ${ }^{128}$ and certainly did not draw a consistent answer from him. 'A statute must not be construed as changing the common law,' he contended in 1933, 'unless a clear intention to do this is shown, and then only to the extent to which the intention to change is clearly shown'.129 But he would have a change of heart: the principle that statutes should be 'construed so as to depart as little as possible from the rules of common law or equity' is, he claimed in 1937, 'an unsafe guide in days of modern legislation'.130 If statutory words fail to yield a clear meaning - if, say, they 'are fairly capable of two interpretations, one of which seems to be in harmony with what is just, reasonable and convenient, while the other is not' - a court will obviously interpret them 'in accordance with ... what seems to be reasonable'. ${ }^{131}$

The reference to modern legislation is signal. The first half of the twentieth century had seen statute law flourish, and Wright knew that judges minded to think of the law primarily as common law would need to re-assess the landscape. '[T] he function of law in our day has become not less, but even more, pervasive', he wrote in 1946. 'It has also become more complex, because of the constant legislation needed to give effect to purposes of social welfare and also to grapple with the great changes consequent on the changes in external life, due to the transition from the simpler days of more primitive mechanical power through macadamized roads and canals to railways, motor transport, and airplanes. ${ }^{132} \mathrm{Re}-$

\footnotetext{
${ }^{126}$ LEA 408.

${ }^{127}$ LEA 382

${ }^{128}$ See LEA 397 ('the statutory portion of law ... is mostly for the specialist and has little interest for the student of law'); also his speech on the Public Order Bill 1936: 103 Parl. Deb. H.L. (5 ${ }^{\text {th }}$ ser.) col. 840 (15 Dec. 1936) ('After somewhat long and tedious experience of construing Acts of Parliament, I have come to the conclusion that one of the greatest difficulties in draftsmanship is too much elaboration, too much definition').

${ }^{129}$ Lochgelly $\mathrm{v}$ M'Mullan, 24 (decided 1933).

${ }^{130}$ LEA 396. See also Milne v Commissioner of Police for City of London [1940] A.C. 1, 38-39; New Brunswicke Railway v British \& French Trust Corp. [1939] A.C. 1, 33-34.

131 Rowell v Pratt [1938] A.C. 101, 105 (decided 1937).

132 Wright, 'Atkin' (P.B.A.) 308.
} 
assessment in the light of '[a]ll these enormous changes' and 'their effect on the growth of law' demanded the conclusion that legal principles are not 'dry or abstract' but 'human', 'practical[', to 'be tested and examined by the criterion of social utility. ${ }^{133}$

But he thought it important not to push this re-assessment too far. By the mid-twentieth century, law might have been at the service of societal goals more than ever before, but ' $[\mathrm{s}]$ till ... the vital principles remain in essence as far reaching and as fundamental'; ${ }^{134}$ law in society is still law, to be interpreted and applied using traditional legal conventions and methods. In 1937, the House of Lords considered the Agricultural Marketing Act 1931, which accorded to government departments public interest immunity from disclosure of information but did not extend the immunity to non-governmental public bodies such as the Potato Marketing Board. Was this failure to extend Crown privilege deliberate? Of late, 'Parliament has established so many new institutions and bodies,' Wright observed, 'and has imposed on individuals so many duties and disabilities for which in the former law no precedents can be found', ${ }^{135}$ that one could only hazard a guess. But the guesswork was unnecessary, he continued, because the wording of the statute was clear: it limited Crown privilege to government departments, and the Potato Marketing Board was not a government department. ' $\Pi \mathrm{f}$ the words properly construed admit of only one meaning, the Court is not entitled to deny to the words that meaning, merely because the Court feels that the result is not in accordance with the ordinary policy of the law or with what seems to be reasonable. The Court cannot mould or control the language'. ${ }^{136}$ Keeping with a traditional method of statutory construction was not, in this instance, a reactionary tactic: the consequence was that non-governmental public bodies were denied immunity from disclosure. Indeed, a judge who is faithful to tradition is not necessarily resistant to innovation: of course the common law struggles to keep apace of legislative development, but 'by its traditional method of judicial legislation by means of judgments on concrete cases' it 'can and will correct its own determinations' and will strive to take account of, even if it cannot move apace with, 'the humanitarian and social ideas of to-day.' 137 Innovative traditionalism is something very different from progress through rule-scepticism: for Wright, moving the law forwards meant not tearing up the script and improvising but going back to it and scrutinizing it for nuances.

Consider in this regard his efforts to develop statutory duties to protect workmen's compensation. We have seen already that, in a number of cases decided in the 1930s, he mounted an assault on the doctrine of common employment. Around the same time, and in tandem with Lord Atkin, he embarked upon another, complementary objective: improving the principles of workmen's

133 ibid 308-309.

134 ibid 308.

135 Rowell v Pratt, 105.

136 ibid.

137 LEA 347-348. 
compensation and incorporating them into the expanding domain of tort liability by requiring employers to provide a safe system of work. In 1940, he argued successfully against the principle that a claimant who accepts a compensation award necessarily relinquishes the right to appeal against that award. ${ }^{138}$ In another case reported that year, he rejected the claim that liability under s. 1 of the Workmen's Compensation Act 1925 (which extended to accidents arising out of as well as sustained in the course of employment) could be avoided if the employer can show that the employee, having been sent to a particular location, suffered injury or fatality the risk of which was equally applicable to everyone in that location. ${ }^{139}$ And in Noble v Southern Railway, again in 1940, he successfully argued that if an employee ignores a workplace safety notice neither out of necessity nor because instructed to do so by his employer, and there is no evidence that the employee acted thus in order to fulfil a purpose not in connection with his employment, the correct inference in the event of his injury or death is that the accident must have arisen out of the course of his employment under the terms of s. 1, and that the employer therefore cannot be exempt from liability. ${ }^{140}$

In all of these cases, Wright sought to apply hard logic to the facts, and he was sometimes clearly exasperated with those who appeared to do otherwise. ${ }^{141}$ Yet, when reading these cases, one cannot help but wonder whether there was some significant emotional investment on his part, too. In Noble, for example, the employee had clearly acted contrary to a notice which the employer had posted in the interests of his safety; the employee was deemed to have acted in the course of his employment, furthermore, for no reason other than that there was insufficient evidence to conclude he had not acted thus. Two years later, Wright was involved in a case in which an employee who sustained a chronic ankle injury at work refused to undergo surgery which would, if successful, have restored his weightbearing capability. The employee had received conflicting surgical reports regarding the risk involved in the operation, and two years after sustaining the

\footnotetext{
138 Lissenden $\mathrm{v}$ Bosch [1940] A.C. 412. For Wright, the principle delivered 'a shock to one's sense of justice. Here is a working man, who in order to seek relief has to come to this House as a pauper because he has been held to be barred from his statutory right of appeal not by anything in an Act of Parliament but by a judicial decision' (ibid 431). But note that in seeking to abolish the principle he insisted that he was rectifying something that was 'erroneous in law' (ibid) rather than acting on his instinct. See also ibid 434, 436

139 See Dover Navigation Co. v Craig [1940] A.C. 190, 202, 204 ('In the present case the answer to the question seems clear and inevitable. The seaman sustained the fatal injury because his employment took him to a river or a roadstead or a sandbank on which his vessel grounded on the West Coast of Africa.... I do not know that [he] was subject to any special or peculiar risk... But [that] appears to me to be irrelevant. The seaman is not exposed to the risk because he is an inhabitant of the place but because he is specially taken to the dangerous place by his employment').

140 See Noble v Southern Railway [1940] A.C. 583, 599 ('In proceeding to East Croydon station [the appellant's husband] was doing what his employment required him to do. His motive, in the narrower sense of the immediate urge in choosing to go by the prohibited route is immaterial, whether it was to save time or to save himself trouble.... [] t is in my opinion impossible on the facts of this case to arrive at any conclusion other than that the man was proceeding for the purposes of and in connection with his employer's trade or business').

${ }^{141}$ See, e.g., ibid 600
} 
injury was still receiving weekly compensation payments under the Workmen's Compensation Act. Wright's legal view of the matter was no different from that of the other law lords deciding the case: the employer has the burden of proving that an employee's refusal to undergo the operation is unreasonable, and in this instance that burden had not been discharged. It is the language that Wright used, however, that marks him out. The matter has to be approached, he insisted, 'in a humane and liberal spirit, realizing that the question cannot be decided save on a sympathetic estimate of the workman's personality'. ${ }^{142}$ Not only is 'it not very logical to say that the workman's refusal breaks the chain of causality between the accident and the incapacity' given that the 'effects of the accident still remain', but '[t]he operation ... may not be successful, even if it is not refused.' ${ }^{143}$ It is important, he continued, not to lose sight of the fact that this must have been preying on the employee's mind. 'Quite apart from the surgical evidence in the particular case, ... the workman's own physical or mental idiosyncracy [sic] cannot in general be excluded. ${ }^{144}$ Wright not only decided in favour of the employees in these worker compensation cases but - this is what distinguishes him - he spoke as if he understood their plight.

Perhaps he did. It is worth recalling that Wright was a judge with a somewhat unconventional background: a man who grew up, and until the age of twenty-four remained, in the North East of England, who was privately educated (which may well mean educated at home) rather than the product of a famous school, who was the son not of an aristocrat or public figure but of a civil servant with whom he may have worked for a while before going to university. Approximately three miles south-west of Wright's home town of South Shields is Jarrow, from where, in 1936, 200 men marched to Westminster to protest about conditions in the North East. Around seventy per cent of the working population in the area was unemployed; labourers were, of course, the principal sufferers, though middleclass occupations - such as that of Wright's father - were also affected. Whether Wright's roots have any bearing on his attitude towards workers' rights we cannot know - even if we knew more about his background and upbringing, there is no way to verify that his history had an impact on the judicial decisions - but the possibility cannot be discounted.

The possibility is worth bearing in mind when considering Wright's speech in the Crofter case of 1941, in which a union, in liaison with dockers, imposed an embargo on imports of tweed cloth from the UK mainland so that everyone working in the tweed industry on the island of Lewis would have to purchase a more expensive yarn woven by local crofters. Most islanders working in the industry already bought their tweed locally, and were also members of the union as indeed were the dockers (who did not breach their employment contracts in imposing the embargo). Weavers who had been buying their cloth from the

\footnotetext{
142 Steele v Robert George \& Co. [1942] A.C. 497, 504

143 ibid 503.

144 ibid.
} 
mainland alleged that the union and the dockers had engaged in a tortious conspiracy to injure. Precedent seemed to be on their side. ${ }^{145}$ But Wright took the view that the precedent was there to be distinguished. This marked him out not at all from the rest of the House in Crofter. What did mark him out was his precisely argued, if occasionally digressive, explanation of why this has to be so. Clearly there was a combination as between the union and the dockers, he observed, ${ }^{146}$ but this did not mean there was a conspiracy to injure. If there is a conspiracy to injure then there is a tort giving a cause of action, but there cannot be a tort if the appellants' complaint is merely that their 'right to freedom in conducting their trade has been interfered with'; for the very nature of market competition - the capacity of powerful commercial actors to set economic terms that the comparably less powerful may be unable to refuse - makes it impossible for that right to be 'an absolute or unconditional right.' 147 The classic American legal realist deployment of this argument - on which Joseph Gold was relying when he castigated common-employment doctrine - tended to lament the capacity of big business to exercise private government over vulnerable individuals. ${ }^{148}$ But Wright recognized that the argument cuts two ways: vulnerable individuals, suitably organized so that they act together, may have the same capacity. 'Where the rights of labour are concerned, the rights of the employer are conditioned by the rights of the men to give or withhold their services. The right of workmen to strike is an essential element in the principle of collective bargaining. ${ }^{149}$ This was, at a time when the common law was still hostile to combinations, a radical claim for a law lord to make.

It was, nevertheless, a claim which Wright considered logically supportable. The tables had been turned, he was saying: if it is not a legitimate reason to interfere with freedom of contract because the economically advantaged have more bargaining power than the economically weak, there is equally no reason to interfere with such freedom when the economically weak combine to take the upper hand. One might even say that we reap what we sow:

English law ... has for better or worse adopted the test of self-interest or selfishness as being capable of justifying the deliberate doing of lawful acts which inflict harm, so long as the means employed are not wrongful. The common law in England might have adopted a different criterion... But we live in a competitive or acquisitive society, and the English common law may have felt that it was beyond its power to fix by any but the crudest

\footnotetext{
145 Quinn v Leathem [1901] A.C. 495 (H.L.).

146 Crofter Hand Woven Harris Tweed Co. v Veitch [1942] A.C. 435, 461.

147 ibid 463.

148 See, e.g., M. R. Cohen, 'Property and Sovereignty' (1927) 13 Cornell L.Q. 8, 12 ('not only is there actually little freedom to bargain on the part of the steel worker or miner who needs a job, but in some cases the medieval subject had as much power to bargain when he accepted the sovereignty of his lord'). See also n 106, above.

149 Crofter v Veitch, 463. Emphasis added.
} 
distinctions the metes and bounds which divide the rightful from the wrongful use of the actor's own freedom. ${ }^{150}$

So it is that the union and the dockers were adjudged to have been pursuing their legitimate interests - seeking to improve wages, to extend union membership, to increase market share. Pursuing these interests may have caused harm to others in the same way that competing successfully in the marketplace might put a rival company out of business and leave its employees without jobs. But the principle is straightforward: 'motive is immaterial in regard to the lawful act of an individual'. ${ }^{151}$ Whether it makes sense to treat Wright's uncompromising statement in support of the right to strike as evidence of his sympathy for the working man is questionable: the House of Lords' decision in Crofter was a decision for one group of workers against another (i.e., the non-unionized local weavers on Lewis who relied on yarn imported from the mainland). Speculations inspired by biography do not take us very far. What seems clear, however, is that in Crofter Wright was adopting what by now ought to be his recognizable rhetorical style: justifying an innovative or progressive stance (in this instance, his support for the right to strike) by using traditional legal principles (in this instance, laissez-faire and damnum sine injuria).

\section{FROM CAUSATION TO RESTITUTION}

Wright's handling of legal authorities epitomizes his innovative traditionalist style. But if we are to obtain a deeper understanding of that style we need to shift our attention from his specific attempts to distinguish precedents and extend the range of statutes and focus instead on how he attempted, with considerable subtlety and lawyerly ingenuity, to reformulate various principles of liability. Some of these reformulations wound their way into the fabric of the common law, though sometimes his arguments met with rejection because - as he himself appreciated they required too radical a break with tradition. In attempting to piece together his obligations jurisprudence I shall start where he starts, with the concept of causation, and then analyse his major judgments on commercial contracts before rounding off the enquiry with an explanation of his (by the standards of the day) distinctly un-English argument for a law of restitution. Although I use these categories - causation, commercial contracts and restitution - to impose some structure and discipline on the account that follows, it is important to keep in mind the core claim that Wright's contributions to each of these areas of law flow from the same premise: that the question of whether a person should be held

150 ibid 472

151 ibid 468. 
responsible for an outcome depends on whether it is just and reasonable to say that what transpired could have been anticipated.

\section{CAUSATION}

Much of the litigation that came Wright's way while he was a barrister during World War I concerned maritime risk insurance. Typical maritime insurance cases concerned whether a ship-owner whose ship was being navigated without lights should incur collision liability, or whether navigating without lights is a legitimate defensive measure which accords with Admiralty instructions. ${ }^{152}$ Also typical were combined causation cases. A ship is torpedoed but is kept afloat with the assistance of tugs and should make it safely to harbour. But the weather becomes so stormy that the ship suffers further damage and sinks. The ship-owners' insurance policy covers storm damage, but exempts the insurers from loss attributable to the consequences of hostilities. ${ }^{153}$ Is the ship-owners' policy worthless to them? It is not worthless if one regards the last cause as decisive. Wright's view, which the House of Lords unanimously accepted, ${ }^{154}$ was more sympathetic to the underwriter. Treating the last cause of a loss as the determinate cause, he argued, is to fail to accord significance to the network of events which conclude with the loss: the event which broke the camel's back is only capable of doing so because of events which preceded it. ${ }^{155} \mathrm{Few}$ cases admit of a genuine last opportunity and, in those instances where there is such an opportunity, to 'cut off the 'last act or omission' and treat it 'as the decisive cause' among the 'combined and composite interacting causes' is 'an offence against common sense', for it means not 'recognis[ing] that the potent effectiveness of earlier causes may count for more than later operations.' ${ }^{\prime} 56$

But if it is a mistake to treat the last act or omission as the determinate cause, which acts and omissions should be relevant for the purpose of establishing

\footnotetext{
152 See, e.g., Britain Steamship Co. v The Crown (1920) 3 Ll. L. Rep. 163, H.L. (Wright representing shipowner/appellant); British and Foreign Steamship Co. v The King [1921] 1 A.C. 99, H.L. (Wright representing shipowner/appellant).

${ }^{153}$ See Leyland Shipping Co. v Norwich Union Fire Insurance Society, Ltd [1918] A.C. 350.

${ }^{154}$ Lord Shaw expressed his 'sense of indebtedness to Mr. Wright for the brief but most cogent argument with which he assisted the House.' Leyland Shipping Co. v Norwich Union Fire Insurance, 371.

155 See ibid 352-353; also Lord Wright, 'Notes on Causation and Responsibility in English Law' [1955] C.L.J. 163, 166-168.

156 Lord Wright, 'Contributory Negligence' (1950) 13 M.L.R. 2, 21, 10, 9. The argument he sets out here was accepted by the House of Lords (with Wright sitting) in Yorkshire Dale Steamship Co. v Minister of War Transport [1942] A.C. 691. Note that the argument is not that all losses must be attributable to an unbroken chain of causation. Wright did not deny the possibility of the novus actus interveniens which undermines the claim that an injury flows directly from a particular act or omission. His point, rather, is that causal connections are negated only by a particular type of intervention. 'The mere fact that human action intervenes', he observed, 'does not prevent the sufferer from saying that injury which is due to that human action as one of the elements in the sequence is recoverable from the original wrongdoer.... To break the chain of causation it must be shown that there is something [sc., an act or omission] which I will call ultroneous, something unwarrantable, a new cause which disturbs the sequence of events, something which can be described as either unreasonable or extraneous or extrinsic.' The Oropesa [1943] P. 32, 37, 39 (C.A.).
} 
liability? That we intended some harm - that we acted or abstained from action in order to bring the harm about - is obviously a reason for attributing to us the consequences of our (in)action. That other causes may intervene between our action and the end intended by our action 'does not nullify'157 our culpability - if causes did operate thus, the doctrine of last act or omission would not offend against common sense - nor, in Wright's opinion, can someone who deliberately chooses to bring about a harmful state of affairs mitigate his wrong by claiming that his action 'did more harm than he intended.'158 The fact that some harm can be attributed to us because we intended it to come about, however, does not mean we must incur liability for that harm: 'causation' - my causing a struggling business to fail, say, because I have set up directly in competition with it - 'does not necessarily import responsibility."159 Damage attributable 'to the legitimate exercise of a right', even damage contemplated by the actor, 'is not actionable. ${ }^{160}$

That an outcome was a foreseeable consequence of our action does not mean we must have intended it. ${ }^{161}$ We should certainly incur liability for the foreseeable consequences of many of our actions, but to which actions should liability attach? The Court of Appeal's decision in Re Polemis - that one could be liable for all the direct consequences of a negligent act, even if those consequences could not reasonably have been anticipated - did not find favour with Wright. In Polemis he represented the defendants, and contended unsuccessfully that they should have been liable only for the natural and probable consequences of their action, and not for consequences which no reasonable person would have anticipated following from such action. ${ }^{162}$ After Donoghue v Stevenson - a decision which Wright very much welcomed ${ }^{163}$ - Polemis seemed to him especially baffling. If there is negligence $-\mathrm{a}$ failure in one's duty of care - and damage which is directly traceable to that negligence, the question of foreseeability would seem to be irrelevant: 'I do not see how foreseeability matters', Wright observed in 1938, 'once a duty of care towards the victim is made out'. ${ }^{164}$ Certainly, he believed, liability for negligence ought not to be extended to new situations solely on the ground that the harm suffered by the plaintiff was a direct consequence of the defendant's negligent act. 'The law cannot take account of everything that follows a wrongful act' he observed in 1933. 'In the varied web of affairs, the law must abstract some

\footnotetext{
${ }^{157}$ Lord Wright, n 156 above, 10.

158 LEA 101

159 See Lord Wright, n 156 above, 6.

160 Bourbill v Young [1943] A.C. 92, 106.

161 See LEA 101; also Lord Wright, n 156 above, 8. I foresee jet-lag before taking long-haul flights, for example, but never intend to suffer it.

162 See Re Polemis [1921] 3 K.B. 560, 564. The facts of the case were that the defendants had chartered a ship from the shipowners, Polemis, for a voyage from Nantes to Casablanca. During unloading at Casablanca, a plank was dislodged in the ship's hold by the defendant's servants. The plank caused a spark which ignited benzine vapour in the hold, and he ship was destroyed. At arbitration it was found that the defendant's servants had been negligent in dislodging the plank and that the plank caused the fire, but that the fire was not a reasonably foreseeable consequence of the plank being dislodged.

163 See G. Lewis, Lord Atkin (Oxford: Hart, 1999 [1983]) 51.

164 LEA 117
} 
consequences as relevant, not perhaps on grounds of pure logic but simply for practical reasons.' 165

Wright elaborated his argument a decade later, in Bourbill v Young. His speech in that case is an object lesson in innovative traditionalism. He manages to refer to Polemis approvingly while maintaining his own position that people should not be liable for consequences which cannot reasonably have been foreseen as following from their actions. ${ }^{166}$ Bourbill concerned the possibility of a duty of care being owed to someone with 'peculiar susceptibilities or infirmities ... which the defendant neither knew of nor could reasonably be taken to have foreseen.'167 When a motorcyclist, driving at excessive speed, collided with a car and was killed, a pregnant woman approximately 45 feet from the incident who heard the crash but did not see it claimed to suffer debilitating nervous shock as a consequence. Her baby, whom she carried to term, was delivered stillborn a month later. Did the requirement of due care extend to awareness of a person's peculiar susceptibility to particular harm?

For Wright, indeed for the House of Lords, it did not. The proposition that the wrongdoer must take the victim as he finds him is only true, Wright reasoned, 'on the condition that the wrong has been established or admitted. The question of liability is anterior to the question of the measure of the consequences which go with the liability.'168 In Bourbill, the wrong had not been established. 'I cannot accept', he concluded, 'that ... the reasonable hypothetical observer could reasonably have foreseen, the likelihood that anyone placed as the appellant was, could be affected in the manner in which she was. In my opinion, [the motorcyclist] was guilty of no breach of duty to the appellant, and was not in law responsible for the hurt she sustained.'169 One should not be liable for the consequences of one's (in)action if one cannot reasonably have been expected to have foreseen those consequences, and that is as true when he who suffers as a consequence of one's (in)action has a peculiar vulnerability, Wright believed, as when he has not.

The statement that the question of liability is distinct from 'the measure of the consequences which go with the liability' is not pedantry on Wright's part. The Court of Appeal in Re Polemis, by attaching liability to all the direct consequences of a negligent act, even those consequences which could not reasonably have been foreseen, had, he insisted, conflated negligence with damages. Lord Blackburn argued in 1870 that liability should be incurred for all damages which flow naturally from the wrongdoer's wrongful (in)action, even if the wrongdoer could not have foreseen the scale of the damage. ${ }^{170}$ This principle, Wright believed, goes

\footnotetext{
165 The Liesbosch v The Edison [1933] A.C. 449, 460.

166 See Bourbill v Young, 109-110. He repeats the trick in his article, 'Re Polemis' (1951) 14 M.L.R. 393, 408.

167 Bourbill v Young, 109.

168 ibid 110.

169 ibid 111

170 Smith $\mathrm{v}$ London \& South Western Ry. Co. (1870-71) L.R. 6 C.P. 14, 22-23 (Exchequer Chamber). Wright saw no contradiction between this principle and the decision in Hadley v Baxendale (1854) 9 Ex. 341 (that a
} 
to compensation (the measure of damages) rather than to culpability (responsibility). ${ }^{171}$ If one's culpability is established, damages should be calculated according to what the victim would have rightfully received or possessed had the wrong not occurred; this could amount to considerably more than the restoration or replacement of the object or value of which the victim has been deprived. ${ }^{172}$ Wright cited as a peculiar outgrowth of this line of reasoning Banco de Portugal v Waterlow \& Sons, ${ }^{173}$ a case in which the House of Lords affirmed one of his own trial judgments. The defendants, who printed bank notes for the Portuguese bank, were duped into delivering 580,000 notes almost identical to the bank's to a criminal gang, who immediately put the false notes into circulation. By delivering these notes to the criminal gang the printing firm was clearly in breach of its absolute duty to the bank not to print or deliver notes without the bank's authority. Nobody could be sure, once the fraud was discovered, which notes in circulation were genuine bank-notes and which were fraudulent. The bank, in order to save the currency, called in all the notes and exchanged them for new ones. Strange though this series of events was, it was clear that the damage was a direct or natural consequence of the printing firm issuing the false notes in breach of contract. How were damages to be measured? Two members of the House of Lords took the view that the damages extended only to the price of recalling the existing notes and issuing the replacements - to the price of the notes as paper. But the majority (Sankey, Atkin and Macmillan) agreed with Wright that the bank was entitled to recover the value of the notes not merely as paper but as currency, because this is what the notes became once the damage occurred. ${ }^{174}$ The printer would be liable for the whole damage; that he could not have reasonably foreseen the extent of that damage was immaterial. ${ }^{175}$

\section{Commercial Contracts}

Wright was no Austinian positivist. Although '[a]t the back of' a legal rule there 'is the power of the State to compel obedience, ${ }^{176}$ the command theory inadequately accounts for the fact that in the hands of judges 'rules of law ... are sometimes

claimant will be unable to recover losses resulting from breach of contract unless the losses are a natural consequence of the breach or are, at the time the contract is made, losses which the parties recognize as ones which in the circumstances may result from the breach), because that case 'refers to both parties' contemplation and I think refers to contemplation in fact', and also 'dealt only with damages in contract.' Wright, 'Re Polemis', n 166 above, 395. His argument appears to be based upon that advanced by counsel for the respondents in Monarch Steamship Co. v Karlshamms Oljefrabriker [1949] A.C. 196, 203-204 where the House of Lords, Wright included, held in the respondents' favour.

171 Cf. Weld-Blundell v Stephens [1920] A.C. 956, 984, H.L., per Lord Sumner (What a defendant ought to have anticipated as a reasonable man is material when the question is whether or not he was guilty of negligence, that is, of want of due care according to the circumstances. This, however, goes to culpability, not to compensation').

172 See Wright, 'Re Polemis', n 166 above, 404.

173 Banco de Portugal v Waterlow \& Sons [1932] A.C. 452.

174 See Banco de Portugalv Waterlow, 476, 490-491.

175 See Wright, LEA, 121, 149-151; 'Re Polemis', n 166 above, 404-405.

176 LEA 188. 
more like rules of thumb'. ${ }^{177}$ ' $[\mathrm{E}]$ xperience of particular cases shows that ... rules, if rigidly applied, will at times produce absurd and irrational consequences', and so legal rules are sometimes treated as 'prima facie presumptions' which will 'admit exceptions. ${ }^{178}$ Even if the consequence of applying a rule is not quite absurdity or irrationality, its application might still not be desirable if doing so offends against 'good sense and practical utility'. ${ }^{179}$ And so judges should be attentive to agents' generally accepted standards of behaviour in particular contexts and should be careful not to apply the law so as to undermine those standards where they have a long-established hold over how agents conduct themselves.

Commercial law, Wright insisted, provides many an illustration of this point. 'Commercial law has always been ready, so far as possible, to sacrifice pedantic logical consistency in favour of the convenience in the conduct of business', he observed in 1939.180 The sacrifice has proved necessary, for, in the words of Roscoe Pound - words which Wright quoted with approval - when the laws of commerce 'stood in the way of many things which the exigencies of business called for ... business men found themselves doing in reliance on each other's business honor ... with or without assistance from the law. ${ }^{181}$ Wright put this lesson into practice in Hillas $\mathrm{v}$ Arcos, one of the earliest cases to come before him as a Lord of Appeal. The appellants purchased timber from the respondents under an agreement which contained an option for the appellants to purchase additional timber at a 5 per cent reduction on the prevailing purchase price. When the appellants sought to take advantage of the option clause, the respondents alleged that it was not a binding agreement but an agreement to make an agreement the terms of which were not defined, and which was therefore unenforceable without further negotiations and agreement between the parties. Technically speaking, the respondents had a point. The option clause did not specify or provide any means for ascertaining the standard, quantity or size of additional timber to be supplied, nor did it state the price of the timber (as opposed to the price reduction) or the terms of delivery. If failure to honour the option was held to be a breach of contract, the determination of an appropriate measure of damages would require a court to import into the contract 'reasonable' contractual terms regarding, among other matters, quality and measurements of the timber to be supplied.

The House of Lords, reversing the Court of Appeal, was unanimously of the view that the necessary terms could be read into the option clause, and that the clause was valid and enforceable as a contract because of the parties' previous dealings. In the particular commercial context there were established standards of

\footnotetext{
177 LEA 192.

178 LEA 167-168.

179 LEA 251.

180 Northumbrian Shipping Co. v Timm [1939] A.C. 397, 409. See also Lord Wright to A. L. Goodhart, 4 July 1936, in Goodhart papers, Bodleian (Special Collections), MS Eng. c. 2891 ('I cannot help wondering whether much help is likely to be got from the business world. My experience is that they take their Law ready made, and from their legal advisors (who are always at hand) ...').

181 R. Pound, An Introduction to the Pbilosophy of Law (Hew Haven: Yale University Press, 1922) 156; cited after Wright, LEA 319.
} 
behaviour, in other words, which made it appropriate to infer the existence of a binding agreement. 'If ... what is meant [by the option clause] is that the parties agree to negotiate in the hope of effecting a valid contract,' Wright reasoned, ' $[\mathrm{t}] \mathrm{here}$ is ... no bargain except to negotiate' - though agreement to negotiate could itself be contractually binding. ${ }^{182}$ ' $[T]$ he parties here did intend to enter into, and did enter into, a complete and binding agreement not dependent on any future agreement for its validity', 183 because the clause gave the appellants 'the option of accepting an offer ... so that when it was exercised a contract at once came into existence.' 184

What, however, of the objection that the terms of this option were not sufficiently certain and complete? A court should not 'make a contract for the parties, or ... go outside the words they have used,' Wright continued, 'except in so far as there are appropriate implications of law, as, for instance, the implication of what is just and reasonable ... where the contractual intention is clear but the contract is silent on some detail. ${ }^{\prime 185}$ In this instance, the implications making it appropriate to spell out a contract were present. It was true that the price of timber to be bought under the option clause was 'uncertain and contingent': 186 it was not accompanied by a price list for different timber types. 'But in past years in the conduct of this business it had been an invariable practice of the respondents to issue such a list', and it was inevitable in this instance that, eventually, they would have issued a list - 'it is difficult to see how the respondents could carry on the[ir] business unless' they did. ${ }^{187}$ It was also true that the description of the goods for supply under the option clause was vague. In past dealings of this type, however, this had proved to be 'not of insuperable difficulty'. ${ }^{88}$ 'In practice', parties in the position of the respondents and the appellants had 'work[ed] out ... necessary adjustments by a process of give and take in order to arrive at an equitable or reasonable apportionment on the basis of the respondents' actual available output, according to kinds, qualities, sizes'; and of course, if this process breaks down, there is no reason the law should not then 'be invoked to determine what is reasonable in the way of specification, and thus the machinery is always available to give the necessary certainty.' ${ }^{189}$

In Wright's view, the point is simple. 'It is ... the incurable habit of commercial men in their contracts not to anticipate or expressly provide for all that may happen.' ${ }^{190}$ And so contracts for future performance will often be incomplete or uncertain in the sense that 'the parties may neither be able nor desire to specify many matters of detail' - matters 'such ... as prices or times of

\footnotetext{
182 Hillas v Arcos, 369.

183 ibid 371.

184 ibid 369.

185 ibid 367.

186 ibid 369

187 ibid.

188 ibid 370

189 ibid 369-370.

190 LEA 258.
} 
delivery in contracts for the sale of goods' - and may have to 'leave them to be adjusted in the working out of the contract.'191 But 'that is not a reason for holding [such contracts] too ambiguous or uncertain to be enforced, if the fair meaning of the parties can be extracted.' 192 'The law, in determining what is reasonable, is not concerned with ideal truth, but with something much less ambitious, though more practical':193

Business men often record the most important agreements in crude and summary fashion; modes of expression sufficient and clear to them in the course of their business may appear to those unfamiliar with the business far from complete or precise. It is ... the duty of the Court to construe such documents fairly and broadly, ... to apply the old maxim of English law verba ita sunt intelligenda ut res magis valeat quam pereat [words are to be understood such that the subject-matter may be preserved rather than wasted]. ${ }^{194}$

Even during Wright's years in the House of Lords there was some reluctance to follow his argument that courts should be willing, in commercial law matters, to see the law play second fiddle to established business practices. Wright himself conceded that the wording in memoranda between commercial agents will sometimes be too inchoate to demonstrate a binding agreement, ${ }^{195}$ and that where commercial agreements are binding it is often better to interpret the terms of the agreement strictly rather than broadly. In 1933, the House of Lords returned to the matter of timber contracts and upheld a purchaser's claim that he could reject goods which, though merchantable and fit for purpose, were not in exact conformity with the description in the contract. Wright was not one of the presiding law lords as he had decided in favour of the purchasers at first instance. His argument - followed by the House of Lords and well summarized by Lord Atkin - was that in this particular instance the understanding among the relevant commercial community was that timber size is not a trivial factor, and that buyers are entitled to reject timber if measurement showed that it did not meet the specifications in the contract. ${ }^{196}$

\footnotetext{
191 Hillas v Arcos, 367.

192 ibid.

193 ibid 370.

194 ibid 367.

195 See, e.g., Scammell v Ouston [1941] A.C. 251, 268 ('The object of the court is to do justice between the parties, and the court will do its best, if satisfied that there was an ascertainable and determinate intention to contract, to give effect to that intention, looking at substance and not mere form. It will not be deterred by mere difficulties of interpretation. Difficulty is not synonymous with ambiguity so long as any definite meaning can be extracted. But the test of intention is to be found in the words used. If these words, considered however broadly and untechnically and with due regard to all the just implications, fail to evince any definite meaning on which the court can safely act, the court has no choice but to say that there is no contract').

196 See Arcos v Ronaasen [1933] A.C. 470, 474 (summary of Wright's judgment) and 479 per Lord Atkin (Although 'there may be microscopic deviations which business men and therefore lawyers will ignore', '[i] $\mathrm{f}$ the written contract specifies conditions of weight, measurement and the like, those conditions must be complied with. A ton does not mean about a ton, or a yard about a yard. Still less when you descend to
} 
After Wright's retirement, the House seemed to retreat yet further from the flexible approach endorsed in Hillas. The clearest example is British Movietonews v London and District Cinemas, decided in July 1951. In 1943 the British government issued an Order, for the purposes of securing public safety and maintaining services essential to the life of the community, which prohibited the supply of newsreel film except under the authority of a licence granted by the Board of Trade. When the War ended the government did not repeal the Order, as had been anticipated, but retained it for the purpose of restricting imports of raw film. When the cinema owners originally contracted to buy film from the suppliers under the terms of the 1943 Order, neither party contemplated that its restrictions would remain in force beyond the War, and so on this basis the cinema owners sought to terminate the contract. Lord Denning, speaking for a unanimous Court of Appeal, concluded that they were entitled to do so owing to Wright's accepted contention that courts may exceptionally go outside the words of a contract in order to infer what is just and reasonable: 'as Lord Wright said, the court really exercises a qualifying power - a power to qualify the absolute, literal or wide terms of the contract - in order to do what is just and reasonable in the new situation.... I] $\mathrm{f}$ the ensuing turn of events was so completely outside the contemplation of the parties that the court is satisfied that the parties, as reasonable people, cannot have intended that the contract should apply to the new situation, then the court will read the words of the contract in a qualified sense.'197

But a unanimous House of Lords reversed the Court of Appeal and rejected Denning's treatment of Wright's reasoning as if it were generally accepted. 'I must at least dissent from the suggestion of the learned Lord Justice [Denning] that the court "really exercises a qualifying power ... in order to do what is just and reasonable in the new situation", Lord Simonds protested. "Nor can I accept the theory ... that in recent cases ... there has been some development of this branch of the law, which would justify such a proposition.... [A]ny change in the ... application of the law of frustration to commercial agreements... can ... be justified on more orthodox grounds.' ${ }^{198}$ The 'more orthodox' basis for qualifying a contract was spelled out by Viscount Simon. 'The parties to an executory contract are often faced ... with a turn of events which they did not at all anticipate. Yet this does not in itself affect the bargain they have made. If ... a consideration of the terms of the contract ... shows that they never agreed to be bound in a fundamentally different situation which has now unexpectedly emerged, the contract ceases to bind ... not because the court in its discretion thinks it just and reasonable to qualify the terms of the contract' - as Wright claimed - 'but because

minute measurements does $1 / 2$ inch mean about $1 / 2$ inch. If the seller wants a margin he must and in my experience does stipulate for it. Of course by recognized trade usage particular figures may be given a different meaning, as in a baker's dozen; or there may be even incorporated a definite margin more or less: but there is no evidence or finding of such a usage in the present case').

197 British Movietonews v London \& District Cinemas [1951] 1 K.B. 190, 200-01 (C.A.).

198 British Movietonews v London \& District Cinemas [1952] A.C. 166, 188 (H.L.). Lords Morton and Tucker concurred without delivering speeches. 
on its true construction' (that is, in light of 'the presumed common intention of the parties') the contract 'does not apply in that situation.'199 An uncontemplated turn of events, in other words, does not provide sufficient reason for a court to replace the contract as it stood with its own notion of what is 'just and reasonable'. Wright's reasoning, according to the House of Lords in 1951, was certainly not broadly accepted.

It has been claimed that the House of Lords, by rejecting Wright's reasoning, was favouring a strict approach to the construction of commercial contracts over a more flexible one. ${ }^{200}$ The claim is certainly understandable. Denning's argument in British Movietonews, after all, was that a court should be allowed to exercise its power to qualify a contract not only when the contract has become impossible to perform but also when there has been a supervening and uncontemplated change of circumstances. But any change of circumstances? '[T] he power which the Court of Appeal purported to exercise', counsel for the film suppliers observed, 'is not one to declare the contract at an end but to do what is just and reasonable, and it does not appear what are its limits. ${ }^{201}$ But the approach favoured by the House of Lords was hardly less vague. The difficulty with presumed common intention as applied to the British Movietonews scenario, Lord Radcliffe pointed out in 1956, is that 'there is something of a logical difficulty in seeing how the parties could even impliedly have provided for something which ex hypothesi they neither expected nor foresaw. ${ }^{202}$ Radcliffe's own approach to the problem was more akin to Wright's. We can guess what the parties might have wanted had they foreseen what happened, but by the time the exercise is complete:

it might seem that the parties themselves have become so far disembodied spirits that their actual persons should be allowed to rest in peace. In their place there rises the figure of the fair and reasonable man. And the spokesman of the fair and reasonable man, who represents after all no more than the anthropomorphic conception of justice, is and must be the court itself. $^{203}$

By the 1950s, there was no doubt reluctance on the part of some senior judges to take Wright's approach to commercial contracts problems. It would indeed be incorrect to say that the approach was generally accepted. But this reluctance was not universally shared. The opportunities Wright had to set out and refine his own perspective in a variety of commercial cases that came before the House of Lords

\footnotetext{
199 British Movietonews v London \& District Cinemas (H.L.) 185-186. In referring to 'the presumed common intention of the parties', Simon is quoting with approval from Lord Sumner's speech in Hirji Mulji $\mathrm{v}$ Cheong Yue Steamship Co. [1926] A.C. 497, 510.

200 See Stevens, n 40 above, 388 ('With the war over, ... and especially with Wright's resignation in 1947, the direction and tone of commercial cases changed ... the cases tended to take on a more formalistic cast ...').

201 British Movietonews v London \& District Cinemas (H.L.) 171.

202 Davis v Fareham DC [1956] A.C. 696, 728.

203 ibid.
} 
meant that by the late 1940s his influence in the field of commercial law ran deep. Consider, for example, Luxor v Cooper, in which he purported to 'deprecate ... the attempt to enunciate decisions on the construction of agreements as if they embodied rules of law.'204 If the wording of private agreements should not be interpreted as one might interpret the wording of a statute, how should they be interpreted? Luxor concerned a contract whereby the principal would pay commission to his agent once the agent had sold the principal's property. Although the agent found a purchaser for the property who was willing to meet the principal's terms of sale, the principal decided not to sell. The agent contended that he was nevertheless entitled to the commission because it was an implied term of the contract that the principal would not take action which precluded the agent from earning it. The House of Lords was unanimous in holding that the term should not be implied. For Wright, it was correct to conclude thus for the same reason that it was correct to infer the existence of an enforceable contract in Hillas $\mathrm{v}$ Arcos: that is, if we consider 'some of the more general aspects of the course of business' and apply '[c]ommon sense and ordinary business understanding', ${ }^{205}$ we can see that the result which the court is proposing is the one that any commercial actor looking at the matter impartially would expect.

It is well known that in the ordinary course a property owner intending to sell may put his property on the books of several estate agents with each of whom he makes a contract for payment of commission on a sale. If he effects a sale to the client introduced by one agent, is he to be liable in damages to all the others for preventing them from earning their commission? ... I can find no justification for such a view.... [T] he suggested ... implied term that the principal will not prevent the agent earning his commission ... must be based upon something which under the contract the principal has agreed to do, of such a nature that failure to do it carries the consequence that the agent cannot earn the commission which would have become due if the principal had done what he had promised. For the purposes of the present problem this promise must be that he would complete the contract. Thus it all comes back to the same issue, namely, that there must be some breach of contract for which damages can be claimed.206

This line of reasoning, Wright insisted, has important implications for the doctrine of frustration. A court can only exercise its qualifying power, and find implied terms in a contract on the basis of what is just and reasonable, so long as there is

${ }^{204}$ Luxor v Cooper [1941] A.C. 108, 130. Much the same philosophy is at play in his dissent in Chichester Diocesan Fund v Simpson [1944] A.C. 341, where the majority's decision was that the use in the will of the words 'charitable or benevolent' instead of 'charitable and benevolent' meant that the trust could be neither charitable nor for the benefit of a sufficiently certain class of objects and so had to fail.

205 Luxor v Cooper, 139.

206 ibid 139-142. 
an agreement to start with. ${ }^{207}$ Sometimes, parties think they have reached an agreement but in fact never have agreed because they were mistaken about some detail on which the agreement is dependent; they will have expressed an intention to agree, but this intention 'is ineffective because it fails to operate on the subjectmatter which both parties mutually contemplate as the object of their agreement.'208 And sometimes, parties will in fact agree but some supervening event will make it impossible to carry out the terms of the agreement. If the parties have not formed an agreement, there can be no contract into which a court might imply terms. But what of the agreement that becomes impossible to perform because of a supervening event - is it a valid contract? The answer, Wright thought, is obvious: if the parties would not have gone ahead with the agreement on the same terms had they been able to foresee the event that transpired, then the contract ceases to be and the parties are freed from all claims apart from any that might be applicable to them outside the terms of the dissolved contract. 209

The actual reason for this answer, he believed, had escaped the English courts. Judges were inclined to assume that the doctrine of frustration is an exception to 'the rules as to absolute contracts': 210 there is a contract, and then an event occurs - unanticipated by either party - which makes it unjust to insist that the parties continue to be bound by the contract, and so a court presumes the parties' intention to be that, should such an event transpire, the contract should be avoided. ${ }^{211}$ The doctrine, thus construed, rests on a fiction: since the parties did not anticipate what happened, they could not have formed the intention that is being implied. Wright considered the justification of frustration by reference to this fiction unhelpful. To treat frustration as an implied condition of the contract could only be acceptable 'so long as it is understood that what is implied is what the court thinks the parties ought to have agreed on the basis of what is fair and reasonable, not what as individuals they would or might have agreed.'212 'It is better and simpler' if courts resolve to do away with references to implied intention in such instances and say 'that the Court in the absence of express

\footnotetext{
207 Cf. Heyman v Darwins [1942] A.C. 356, 376 ('the first thing is to ascertain according to ordinary principles of construction what the parties have actually agreed').

208 LEA 261

${ }^{209}$ See LEA 255

${ }^{210}$ Hirji Mulii v Cheong Yue Steamship Co., 510, per Lord Sumner.

${ }^{211}$ See Dabl \& Co v Nelson, Donkin \& others (1880-81) L.R. 6 App. Cas. 38, 59 per Lord Watson (T have always understood that, when the parties to a mercantile contract ... have not expressed their intentions in a particular event ... a Court of Law, in order to ascertain the implied meaning of the contract, must assume that the parties intended to stipulate for that which is fair and reasonable, having regard to their mutual interests and to the main objects of the contract.... There may be many possibilities within the contemplation of the contract ... were not actually present to the minds of the parties at the time of making it, and, when one or other of these possibilities becomes a fact, the meaning of the contract must be taken to be, not what the parties did intend (for they had neither thought nor intention regarding it), but that which the parties, as fair and reasonable men, would presumably have agreed upon if, having such possibility in view, they had made express provision as to their several rights and liabilities in the event of its occurrence').

212 Fibrosa Spolka Akcyjna v Fairbairn Lawson Combe Barbour Ltd [1943] A.C. 32, 70.
} 
intention of the parties determines what is just. ${ }^{213}$ For to say that a finding of frustration

depends on an implied condition of the contract ... is really no explanation. It only pushes back the problem a single stage. It leaves the question what is the reason for implying a term.... The parties did not anticipate fully and completely, if at all, or provide for what actually happened. It is not possible, to my mind, to say that, if they had thought of it, they would have said: "Well, if that happens, all is over between us." On the contrary, they would almost certainly on the one side or the other have sought to introduce reservations or qualifications or compensations. As to that the court cannot guess. ${ }^{214}$

\section{THE ROAD TO RESTITUTION}

In 1935, at the Law Quarterly Review golden jubilee dinner, the editor of the Harvard Law Review apparently persuaded Wright to produce an article for him. ${ }^{215}$ Wright might easily have evaded this task, one assumes, but he did not, and indeed the article he eventually delivered, on the question of whether the doctrine of consideration ought to be abolished from the common law, is possibly his most rigorous and impassioned piece of writing.

Wright answers his question unequivocally in the positive: 'I cannot resist the conclusion that the doctrine [of consideration] is a mere encumbrance. A scientific or logical theory of contract would in my opinion take as the test of contractual intention the answer to the question whether there was a deliberate and serious intention, free from illegality, immorality, mistake, fraud or duress, to make a binding contract.'216 Consideration may be a useful 'piece of evidence' in determining if such intention is present, but it is insufficient actually to prove the parties' intentions and so it cannot logically be 'a condition of the contract'.217 This argument, Wright insisted, is not merely an exercise in logic. The study of various other legal systems - such as those of South Africa, Scotland, France, Germany, Switzerland and Japan - shows that a body of contract rules can function perfectly well without the doctrine of consideration. ${ }^{218}$ Even the common law, he observed, accommodates various instances where consideration is not necessary to the formation of a binding contract. ${ }^{219}$ In instances where consideration is required, an

\footnotetext{
${ }^{213}$ LEA 380, 258.

214 Denny, Mott \& Dickson v James B. Fraser, 275.

215 See LEA xi; also Lord Wright to A. L. Goodhart, 4 July 1936, in Goodhart papers, Bodleian (Special Collections), MS Eng. c. 2891 ('I had promised the young Editor at the Jubilee dinner to do an article for him, and he did not let me forget, so I had no alternative').

${ }^{216}$ Lord Wright, 'Ought the Doctrine of Consideration to be Abolished from the Common Law?' (1936)

49 Harv. L. Rev. 1225, 1251.

217 ibid.

218 See ibid 1233-1238

219 ibid 1247-1251.
} 
offeree might be disadvantaged by its absence, since the offeror may consequently be entitled to vary the terms of, or withdraw, an option to purchase.220 'I see no practical objections to the abolition of the doctrine,' Wright concluded, 'to counterbalance the reasoning on which I have advocated that it should be abolished.'221

The basic argument was hardly novel. Lord Mansfield advanced it in 1765,222 and English lawyers, for a few years at least, received it with some enthusiasm. ${ }^{223}$ By the end of the 1770s, however, the House of Lords had rejected it. '[T] he law of this country supplies no means, nor affords any remedy,' Lord Chief Baron Skynner declared in Rann $\mathrm{v}$ Hughes, 'to compel the performance of an agreement made without sufficient consideration.'224 Even if Wright's reasoning was sound, the doctrine of consideration looked safe. 'A common-law judge could not say I think the doctrine of consideration a bit of historical nonsense and shall not enforce it my court', O. W. Holmes remarked.225 Wright was equally realistic: 'I fear ... that there is little prospect in the near future of the English law being completely changed in so vital a respect,' not least because 'there is a dead weight of legal conservatism to be overcome. ${ }^{226} \mathrm{He}$ did not shirk the challenge of criticizing this conservatism, though his initiative came to naught. In the year following the publication of the Harvard Law Review article the Law Revision Committee, under his chairmanship, issued an interim report recommending, among other things, various alterations to the law relating to the necessity of consideration in contracts. 227 The report encountered strong opposition and the matter never returned to the reform agenda during his lifetime. ${ }^{228}$

Not all of Wright's efforts to make Mansfield prevail in twentieth-century English law met with failure, however. Wright's argument as regards contractual frustration appeared to amount to nothing more than that courts, when they find that frustration has occurred, should base their conclusion not on the finding of an implied term in the contract but upon a claim as to what 'the parties ... as reasonable men ... should have intended' had they been able to foresee the relevant supervening event. 229 On the face of it, the distinction he draws seems neither here nor there. Yet he thought his argument was considered 'somewhat

\footnotetext{
220 See ibid 1231-1232; also Dunlop v Selfridge [1915] A.C. 847, H.L.

221 Wright, n 216 above, 1253.

222 See Pillans v van Mierop (1765) 3 Burr. 1663, 1669.

223 See C. H. S. Fifoot, Lord Mansfield (Oxford: Clarendon Press, 1936) 134-135; J. Oldham, English Common Law in the Age of Mansfield (Chapel Hill, NC: University of North Carolina Press, 2004) 84-87.

${ }^{224}$ Rann v Hughes (1778) 7 Term Rep. 350, 350n (a). This is the report of the judicial opinion. The pleadings and arguments are reported at (1778) 4 Brown P. C. 27.

225 Southern Pacific Co. v Jensen, 244 US 205, 221 (1917) (Holmes J., dissenting).

226 Wright, n 216 above, 1253.

227 Sixth Interim Report: Statute of Frauds and the Doctrine of Consideration: Presented by the Lord High Chancellor to Parliament by Command of His Majesty, May 1937, Cmd. 5449 (London: HMSO, 1945).

228 See Goodhart, n 7 above, 435. The Committee was under no illusions. 'Many of us would like to see the doctrine [of consideration] abolished root and branch', it reported, '[b]ut a recommendation to this effect would probably be unwise. It is so deeply entrenched in our law that any measure which proposed to do away with it altogether would almost certainly arouse suspicion and hostility' (Sixth Interim Report, para. 27).

${ }_{229}$ Joseph Constantine Steamship Line v Imperial Smelting Corp. [1942] A.C. 154, 185.
} 
heretical',230 a surmise perhaps borne out by the House of Lords' unwillingness ever to endorse his reasoning in the way Denning did in British Movietonews. No doubt some law lords would have considered Wright's approach to require a step too far down the path towards unfettered judicial creativity: he was saying, after all, that rulings regarding contractual frustration do not depend upon an applicable statutory provision, a judicial precedent, a term explicit in the contract or even a term which could be implied, but are to be made on the basis of what a court thinks anyone in the position of the parties ought fairly and reasonably to have agreed would happen had they ever anticipated the frustrating event.

But it is still difficult to see that the distinction between the 'reasonableness' approach to frustration questions and the approach of those who settled such questions by invoking implied intention amounted to anything more than a semantic one. It is notable, indeed, that throughout Wright's years in the House of Lords any disagreements he had with colleagues over frustration problems were as to reasoning rather than outcome. ${ }^{231}$ However the differences of approach, though subtle, were significant. Consider Fibrosa v Fairbairn, a case in which the appellants, a Polish company, had paid by way of deposit roughly 20 per cent of the purchase price of expensive machinery to be supplied by the respondents, an English company. The payment was made in July 1939. Germany's invasion of Poland two months later made performance of the contract impossible, and so the appellants sought to reclaim their deposit. The respondents, however, argued that since the German invasion had frustrated the contract it was not enforceable, and so they were under no obligation to return the money the appellants had paid them. This argument was accepted both at trial and in the Court of Appeal on the basis that, according to precedent, ${ }^{232}$ where a contract is frustrated the loss lies where it falls. But the House of Lords overruled this precedent and found for the appellants. For Wright, there was a total failure of consideration - the appellants had received nothing in return for the payment of the deposit - and so, in the absence of a term in the contract dealing with the matter, a determination of a just and reasonable outcome would require the court to consider whether, in the words of Lord Mansfield in Moses $\mathrm{v}$ Macferlan, 'the defendant be under an obligation from the ties of natural justice, to refund'. ${ }^{233}$

Wright was in no doubt that in Fibrosa the obligation was there. Mansfield had provided 'the basis of the modern law of quasi-contract', ${ }^{234}$ he argued, a category

\footnotetext{
230 Denny, Mott \& Dickson v James B. Fraser, 276. See also Lord Wright to James M. Landis, 28 April 1938, in Griswold Papers, XVII. E. 1: folder 305-4 ('I gave two addresses to students at London [LEA 387 $410]$ and Cambridge [LEA 1-33] last year.... One [sc., the Cambridge address], which in fact is regarded here as heretical, will interest Professor [Warren] Seavey').

231 In Cricklewood Property \& Investment Trust v Leighton's Investment Trust [1945] A.C. 221, he appeared to disagree with the majority in House of Lords over the question of whether the doctrine of frustration might ever apply to a lease - he (and Lord Simon) thought that it could - but he agreed with the majority that the facts of the case did not in any event justify the application of the doctrine.

232 Chandler v Webster [1904] 1 K.B. 493, C.A..

233 Moses v Macferlan (1760) 2 Burr. 1005, 1008.

234 Fibrosa v Fairbairn, 70.
} 
which many 'serious legal writers' 235 refused to recognize as relevant to English law. That the issue was the respondents' obligation, not what they had promised, needed to be emphasized: 'Mansfield does not say that the law implies a promise. The law implies a debt or obligation which is a different thing. In fact, he denies that there is a contract; the obligation is as efficacious as if it were upon a contract.'236 In the event of frustration it might be just and reasonable to find a party obliged - even if not contractually obliged - to repay money advanced to him on the basis that not to impose this obligation would be to allow unjust enrichment. The manner in which Wright argued in favour of invoking quasicontract in Fibrosa was distinctive, but the sentiment certainly was not. Requiring the respondents to return the money to the appellants once frustration had occurred did not vary the terms of the contract in any way, Viscount Simon contended, 'because, in the circumstances that have happened, the law gives a remedy in quasi-contract to the party who has not got that for which he bargained'. ${ }^{237}$ True, Simon's reasoning was not Wright's: Simon's argument was based on a modification of the doctrine of mutual promises as consideration rather than on the argument that there should be restitution for unjust enrichment.238 Both men, however, showed no hesitation in concluding that Fibrosa was to be settled by pointing to the existence of a quasi-contract.

It is worth noting that no effort was made in Fibrosa to implement the Law Revision Committee's recommendations for the reform of the rules of frustration as set out in its interim report of 1939.239 The failure of the House to consider these recommendations may seem surprising, given that the Committee was chaired by Wright. But the Committee was in the business, as Wright put it, of 'recasting particular rules which appear to be ill-conceived but which can only be altered by legislation' 240 - legislation which, in this instance, would be passed in the same year that Fibrosa was decided.241 The report of 1939 entailed one compromise after another, and appears not to have contained the ambitious legislative reform proposals that Wright might have hoped for. ${ }^{242}$ That his hopes for far-reaching reform were probably high might be deduced from certain of his extra-judicial observations. These - which perhaps amount to his real act of heresy - make it clear that he wanted quasi-contract, or restitution, recognized as 'a distinct branch of law capable of, and worthy of, careful study. ${ }^{243}$ In this regard he was not a lone voice. Percy Winfield, a fellow member of the Law Revision Committee, had treated quasi-contract in exactly this way (and generated

235 ibid 64 .

236 ibid 62 .

237 ibid 46.

238 See ibid 48.

239 See Law Revision Committee, Seventh Interim Report (Rule in Chandler v Webster), Cmd. 6009 (London: HMSO, 1939).

${ }^{240}$ LEA 349.

${ }^{241}$ Law Reform (Frustrated Contracts) Act 1943.

${ }^{242}$ See P. Mitchell, 'Fibrosa Spolka Akcyjna v. Fairbairn Lawson Combe Barbour, Limited', in C. Mitchell \& P. Mitchell (eds), Landmark Cases in the Law of Restitution, (Oxford: Hart, 2006) 247-283, 259-281. ${ }^{243}$ LEA 27. 
considerable academic debate for doing so) in his Tagore lectures of 1930.244 Other jurists around this time emphasized that continental doctrine provides abundant support for the principle that people should not be permitted unjustly to enrich themselves at the expense of others, ${ }^{245}$ and a significant number of English academic lawyers welcomed, and felt there was much to be learned from, the American Restatement of the Law of Restitution on its publication in 1937.246

But Wright was almost a lone voice among the senior English judiciary of his day. 'Lord Mansfield's language has been completely misunderstood', Lord Sumner claimed, if one interprets him to have been speaking up for the doctrine of unjust enrichment when he said that a recipient of funds is, in the event of a total failure of consideration, under an obligation to repay because of the ties of natural justice. ${ }^{247}$ The action for recovery of money in the event of a failure of consideration was simply 'a form of assumpsit' - a common law action to recover in the event of breach for non-performance of contract - which was 'already old in Lord Mansfield's time' and was certainly 'not devised by the Court of Chancery'. 248 'There is', Sumner insisted, 'no ground ... for suggesting as a recognizable "equity" the right to recover money in personam merely because it would be the right and fair thing that it should be refunded to the payer.'249 Other judges were similarly opposed to the idea that Mansfield had laid the foundations for quasi-contract. ${ }^{250}$ For Wright's mentor, Lord Justice Scrutton, the problem with recognizing quasi-contract as a distinct category of law was not so much historical as analytical. The very notion of quasi-contract struck him as fundamentally obscure: is there a contract or is there not? '[T]he whole history of this particular form of action has been what I may call a history of well-meaning

244 P.H. Winfield, The Province of the Law of Tort (Cambridge: Cambridge University Press, 1931) 116-189. For the academic debate see, in particular, P. A. Landon, 'The Province of the Law of Tort' (1931) 8 Bell Yard 19; P. H. Winfield, 'The Province of the Law of Tort: A Reply' (1932) 9 Bell Yard 32; W. T. S. Stallybrass, 'Landon $v$. Winfield: An Intervention' (1932) 10 Bell Yard 18; W. S. Holdsworth, review of The Province of the Law of Tort [1932] J.S.P.T.L. 40; 'Unjustifiable Enrichment' (1939) 55 L.Q.R. 37. For Wright on Winfield, see his 'Sir Percy Winfield' The Times, (16 July 1953) p.8.

245 See H. C. Gutteridge and R. C. A. David, 'The Doctrine of Unjustified Enrichment' (1934) 5 C.L.J. 204; W. Friedmann, 'The Principle of Unjust Enrichment in English Law' (1938) 16 Can. Bar Rev. 243, 365

246 See, e.g., R. M. Jackson, 'The Restatement of Restitution' (1938) 10 Mississippi L. J. 95; and D. W. Logan, 'Restatement on Restitution' (1938) 2 M.L.R. 153; also H. G. Hanbury, 'The American Law Institute's Restatement of the Law of Trusts' (1937) 2 U.T.L.J. 50, 51 n 3 ('Modern English opinion ... betrays a regrettable neglect of the methods of scientific juridical speculation, and a tendency complacently to ignore the ideas which might be revealed by a careful perusal of the great works of Keener and Woodward on quasi-contract'). In 1938, the Reporters to the Committee on Restitution provided an account for an English audience: W.A. Seavey and A.W. Scott, 'Restitution' (1938) 54 L.Q.R 29.

247 Sinclair v Brougham [1914] A.C. 398, 454. On Sumner's antipathy towards the doctrine of unjust enrichment, see A. Lentin, The Last Political Law Lord: Lord Sumner (1859-1934) (Newcastle-upon-Tyne: Cambridge Scholars Publishing, 2008) 53-56.

248 Sinclair v Brougham, 454.

249 ibid 456

${ }^{250}$ See, e.g., Baylis $\mathrm{v}$ Bishop of London [1913] 1 Ch. 127, 138-140 esp. at 139, per Hamilton LJ ('The truth is that the language of Lord Mansfield's judgment upon the action for money had and received must be applied to other cases with great caution'); Morgan v Ashcroft [1938] 1 K.B. 49, 62-63, per Sir Wilfrid Greene, MR. 
sloppiness of thought. ${ }^{251}$ Not every judge was so dismissive. Lord Justice Greer defended a position akin to Wright's - somewhat tersely and elliptically, it has to be said - in 1936.252 The following year, Lord Justice Scott observed that the circumstances in which a claimant might look to have money or property restored to him 'are so various in kind' that it would be a mistake to close the door on the possibility of courts developing a distinct law of quasi-contractual obligations arising out of unjust enrichment. ${ }^{253} \mathrm{He}$ was unconvinced, nevertheless, that 'the moral principle of "unjust enrichment" $\ldots$ at the present time afford[s] an authoritative criterion by which the Court can decide whether a given claim discloses a cause of action for money had and received. The test is too vague ... even if it was ever a test'. ${ }^{254}$

Even while a judge on the King's Bench Division, Wright had apparently been pondering the possibility of finding quasi-contractual liability in cases concerning receipt of misapplied assets, 255 though it was not until the mid-1930s that he began properly to set out his stall. In Brook's Wharf v Goodman, a case in which he was involved during his tenure as Master of the Rolls, goods imported to the United Kingdom by the defendants were stolen from the warehouse at which they were stored. On receipt of the goods the warehouse owners had been required to pay customs duty, which they were now claiming should be recoverable from the defendants. Wright, speaking for the Court of Appeal, found that the defendants were obliged to reimburse the warehouse the amount of duty paid. 256 The obligation, he said, arose not 'on any ground of implied contract or of constructive or notional contract' but on the basis of 'what the Court decides is just and reasonable, having regard to the relationship of the parties.... The defendants would be unjustly benefited at the cost of the [warehouse owners] if the latter, who had received no extra consideration and made no express bargain, should be left out of pocket by having to discharge what was the defendants' debt.'257 Over the next year, Wright took the opportunity to work out his argument regarding restitution for unjust enrichment more carefully. Five months before the decision in Brook's Wharf, the American Law Institute had adopted its first Restatement on restitution. When the Restatement was published in 1937,,258

\footnotetext{
251 Holt v Markham [1923] 1 K.B. 504, 513.

252 ' $[\mathrm{T}]$ he inference of a promise to pay on a quantum meruit basis ... is not one of fact, but ... an inference which a rule of law imposes on the parties where work has been done or goods have been delivered under what purports to be a binding contract, but is not so in fact.' Craven-Ellis v Canons [1936] 2 K.B. $403,410$.

253 Morgan v Ashcroft, 76.

254 ibid 75-76. By 1938, he seemed somewhat more receptive: see Re Cleadon [1939] Ch. 286, 314-315 (decided 1938).

255 See Liggett v Barclays Bank [1928] 1 K.B. 48, 63-64.

256 Brook's Wharf v Goodman Bros. [1937] 1 K.B. 534. The defendants had counterclaimed unsuccessfully that the goods were stolen owing to the warehouse owners' negligence. Neither party was insured for the loss.

257 ibid 545

258 Restatement of the Law of Restitution, Quasi Contracts and Constructive Trusts, as Adopted and Promulgated by the American Law Institute at Washington, D.C. May 8, 1936 (St. Paul, Minn.: American Law Institute Publishers, 1937).
} 
Wright reviewed it in the December issue of the Harvard Law Review.259 In the month before his review appeared, he delivered a lecture to the Cambridge University Law Society offering a re-evaluation of Sinclair v Brougham, 260 in which the House of Lords refused to uphold a personal action for recovery of money against a company that had acted ultra vires. The lecture appeared in the Cambridge Law Journal in 1938.261 Both works - his assessment of Sinclair v Brougham and of the Restatement - showed Wright to be far more receptive to the development of the law of restitution than was any other English judge of his day.

His starting-point was, on the face of it, an odd one. In Sinclair v Brougham, the House of Lords decided that because money was paid to a company acting ultra vires, the money could not be recovered as if it were a loan. There was no contractual obligation to repay. But equally there was no quasi-contractual obligation to repay. To declare the existence of a quasi-contract in this instance would be to impute the fiction of a promise to repay in the circumstances that had arisen, Viscount Haldane remarked, but 'as matter of principle the law of England cannot ... impute the fiction of such a promise where it would have been ultra vires to give it.'262 Lord Dunedin, while not denying the existence of a general (if often non-executable) equitable right to recover misapplied assets through tracing, was of the same view. ${ }^{263}$ The decision appeared to offer no support for anyone seeking to make a case for quasi-contract as a distinct category of civil liability; indeed, Haldane was insistent that 'the common law of England really recognizes (unlike the Roman law) only actions of two classes, those founded on contract and those founded on tort.'264 If the case offered no support for Wright's arguments, what was he going to do with it?

Wright insisted the case in fact did offer support for his arguments, for it 'shows how the Court can do justice by applying equitable principles where the common law would have been powerless. ${ }^{2} 65$ The money that the claimants sought to recover in Sinclair $\mathrm{v}$ Brougham had become inextricably mixed with other moneys, and so the restoration of money to debtors could only be effected by the 'rough justice'266 of tracing, whereby outside creditors were paid off first and then the shareholders and depositors, neither of which group had priority over the other, could seek to recover their debts according to amounts credited to them in the books of the company at the commencement of winding-up. ${ }^{267}$ The House of

259 (1937) 51 Harv. L. Rev. 369-383, repr. LEA 34-65. See also James M. Landis to Lord Wright, 12 April 1938, in Griswold Papers, XVII. E. 1: folder 305-304 ('Your review of the Restatement of the Law of Restitution in the December number of the Harvard Law Review has been much appreciated and caused not a little comment').

260 [1914] A.C. 398.

261 Lord Wright, 'Sinclair v. Brougham' (1938) 3 C.L.J. 305-326, repr. LEA 1-33.

262 Sinclair v Brougham, 417.

263 See ibid 432-433.

264 ibid 415.

265 LEA 1.

266 LEA 2.

267 Though 'complete restoration' could not be possible given that, in total, the claimants' debts exceeded the company's assets: LEA 4. 
Lords had taken an important step, Wright believed, because it made the test of recovery 'not the loss to the plaintiff, but the gain to the defendant'. 268 Viscount Haldane might have purported to pour scorn on the prospect of applying the principle of unjust enrichment to the facts of Sinclair v Brougham, ${ }^{269}$ but in fact, Wright insisted, this is exactly what the court had done: ' $[t]$ he importance of the case is that it demonstrates a category of claims distinct from contract, or tort, or trust (express or resulting), the essential principle of which is that the defendant should not be unjustly enriched at the expense of the plaintiff. ${ }^{270}$

The more carefully one thinks about this principle, he believed, the less unattractive the prospect of its application as a principle of liability becomes. Much careful thought had been given to the matter by the authors of the Restatement, and if English lawyers could set aside their 'insular self-sufficiency'271 and take this work seriously they would come to appreciate two important arguments in support of the principle: first, that it does not entail a denial of the fact that ' $[t]$ here are many positions in which a defendant may be enriched at the expense of the plaintiff and yet it may not be unjust for him to retain that benefit'; 272 and, secondly, given the possibility of innocent transfer of assets to an unintended recipient (who, but for insolvency, could have been expected to return them), that unjust enrichment does not always equate with the maxim that people should not profit from their wrongdoing. ${ }^{273}$ ' $]$ n Sinclair v. Brougham, the House of Lords were not, it seems, thinking of these particular' issues. ${ }^{274}$ Even if we leave the Restatement out of the picture and confine ourselves to a 'careful study of the English reported cases at law or in equity', we can discover the 'doctrine of unjust enrichment' to be 'that the defendant has received some property of the plaintiff or received some benefit from the plaintiff, for which it is just ... that he should make restitution.'275

Wright's insistence that Sinclair v Brougham was an important decision for reasons rather different from those 'emphasized by some lawyers'276 - that it advanced a principle which the House of Lords appeared to reject - seems strained. But the point of his argument is obvious enough: he was seeking to discredit the idea that restoring assets which it would be unjust for a recipient to keep but which the recipient is not contractually obliged to return necessitates the imposition of an implied contract. We 'ought to put aside once and for all the misleading fiction of an implied contract'277 and recognize that, in those instances 'where a contract is rescinded for breach or illegality or supervening impossibility,

${ }^{268}$ LEA 3

${ }^{269}$ See Sinclair v Brougham, 417.

${ }^{270}$ LEA 2-3.

${ }^{271} L E A$ xiii.

${ }^{272}$ LEA 3.

273 See LEA 13.

274 ibid.

275 LEA 26.

276 LEA 1. The decision was explicitly overruled by the House of Lords in Westdeutsche Landesbank Girozentrale v Islington LBC [1996] A.C. 669.

${ }^{277}$ LEA 358 
the right to restitution (if any) for benefits received depends as a rule on the principles of quasi-contract, if as is generally the case the express contract is silent on the matter.'278 To describe an obligation arising out of unjust enrichment as 'quasi-contractual' is, Wright appreciated, 'not very apt'. ${ }^{279}$ When a court declares the existence of a quasi-contract between parties it is imposing a contractual remedy, even though 'unjust enrichment', liability for which is being treated as establishing that remedy, 'has no relation as a juristic conception with contract at all. ${ }^{220}$ English lawyers tend to fall into the 'error' of confusing 'Implied Contracts, which are true contracts' with 'Quasi-Contracts, which are not contracts', Henry Maine wrote in $1861 .{ }^{281}$ Neither are true contracts, Wright was arguing, but whereas the former concept requires a court to pretend to know what the parties would have agreed had the circumstances been different, the latter is based on the fact that absent an order for return of assets from $B$ to $A, B$ will have been allowed to benefit unjustly. ${ }^{282}$ The House of Lords had decided appropriately in Sinclair $\mathrm{v}$ Brougham by allowing restitution of the money laid out by the claimants. The mistake of the House had been to think that this result could only be reached by finding an implied contract and justifying this finding as a modern example of the indebitatus assumpsit action. ${ }^{283}$ Such 'legal antiquarianism'284 was unnecessary and unhelpful. Rather than resist the establishment of restitution as a discrete category of liability on the basis of 'technicalities and rules which have no claim to exist except on grounds of antiquity', the House ought to follow the example it had set in Donoghue v Stevenson when it 'brushed aside technicalities and simply said that on the facts of the case there was a duty to take care and thus established a broad general rule of negligence. ${ }^{2} 85$ The result is not the creation of a new category of liability just for the sake of it, but 'avoid[ing] what is unconscionable'286 and 'doing justice according to the actual facts, though on the lines of established law.'287

Although it could be claimed that Wright's convoluted effort to keep his argument within the confines of Sinclair $\mathrm{v}$ Brougham is evidence of his regard for tradition - which, at this point in time, still had it that House of Lords precedents could only be overturned by Parliament - the case he was making for the

\footnotetext{
${ }^{278}$ LEA 50.

279 LEA 356 C.L.P. 1, 10-13

281 Sir H. Maine, Ancient Law (London: Murray, 1861) 343-344.

282 See LEA 29-30.

283 See $L E A 30-32$

284 LEA 16.

${ }^{285}$ LEA 384, 385

286 LEA 24; see also 36

287 LEA 385.
}

${ }^{280}$ LEA 15. The notion of contract, that is, including implied contract, 'has nothing to do with' (ibid 19) the defendant's holding of the plaintiff's assets. The fact that the defendant could be a third party and the plaintiff a subrogated surety was evidence, for example, that the finding of liability did not depend on there being privity of contract (see ibid 9, 26, 46-47, 61-62, 384). Privity was, in fact, a concept for which Wright could see little purpose. The Law Revision Committee, in its Sixth Interim Report, called for a reform of the privity rule but the proposal appears to have been stymied because of the difficulty, as the Second World War approached, of finding space for it in the legislative process: see J. Beatson, 'Reforming the Law of Contracts for the Benefit of Third Parties: A Second Bite at the Cherry' (1992) 44 
recognition of quasi-contractual liability was the type of judicial innovation for which Mansfield had been renowned. Certainly part of the argument was in keeping with mid-twentieth century English contracts jurisprudence. The idea that many instances of rescission were best solved by the fiction of the implied contract had fallen out of favour even before Wright had retired from the House of Lords. The indebitatus assumpsit action which became popular in the seventeenth century imputed to the defendant a promise to repay in the event of, say, mistake, deception or failure of consideration, Lord Atkin observed in 1940. But the promise was completely fabricated. "The cheat or the blackmailer does not promise to repay to the person he has wronged the money which he has unlawfully taken: nor does the thief promise to repay the owner of the goods stolen the money which he has gained from selling the goods.'288 Atkin was adamant that the time for this solution had passed.

These fantastic resemblances of contracts invented in order to meet requirements of the law as to forms of action which have now disappeared should not in these days be allowed to affect actual rights. When these ghosts of the past stand in the path of justice clanking their medixval chains the proper course for the judge is to pass through them undeterred.289

Both the sentiment and the language might as well have been Wright's. 'The fictional contract', he had observed in his lecture on Sinclair v Brougham, 'seems to be vanishing more and more, indeed, even the ghost of the form seems to have disappeared.'290 The decision in Fibrosa in 1943 - and particularly Wright's own rejection of implied-contract analysis and his marshalling of Mansfield to find a quasi-contract arising out of unjust enrichment - could well have been the coup de grâce. ${ }^{291}$

Wright, of course, wanted to witness not only the demise of implied-contract analysis but also the emergence of restitution for unjust enrichment as a discrete category of obligations in English law.292 This part of his argument was ahead of its day. 'I do not think that [unjust enrichment] can be a source of civil rights in this country' Lord Radcliffe said in 1950.293 Similarly Lord Porter the following year: 'the exact status of the law of unjust enrichment is not yet assured.... It holds a predominant place in the law of Scotland and, I think, of the United States, but I

\footnotetext{
288 United Australia Ltd v Barclays Bank [1941] A.C. 1, 27 (decided 1940).

289 ibid 29.

290 LEA 19

291 See D. J. Ibbetson, A Historical Introduction to the Law of Obligations (Oxford: Oxford University Press, 1999) 288.

292 See $L E A$ xiv-xv; 16; 207.

293 Boissevain v Weil [1950] A.C. 327, 341. He continued: 'It is very well to say that the respondent ought not in conscience to retain this money and that that consideration is enough to found an action for money had and received. But there are two answers to this. Firstly, when the transaction by which the money has reached the respondent is actually an offence by our laws, the matter passes beyond the field in which the requirements of the individual conscience are the determining consideration. Secondly, an action in this country cannot by its very nature lead to a return of what was borrowed' (ibid).
} 
am content for the purposes of this case to accept the view that it forms no part of the law of England. ${ }^{294}$ According to Lord Diplock, nothing had changed by 1977 - still, he insisted, 'there is no general doctrine of unjust enrichment recognised in English law'295 - notwithstanding that eleven years had passed since English students had first been delivered a textbook on the subject. ${ }^{296}$

There seems little doubt that Wright was engaging in wishful thinking when he asserted, in 1942, that England already had three categories of civil liability. Perhaps, in asserting as much, he was pursuing his broader agenda of seeking 'to exorcise or at least discourage ... a devotion to form ... rather than substance', ${ }^{297}$ though this certainly was not his view of the matter. Recognizing a right to restitution on the basis of established law does not mean that remedies for unjust enrichment should be awarded according to what any particular judge thinks 'justice' requires; indeed, Wright professed himself bewildered by those who interpreted him as wanting to 'give the go-by to precedent and ... reduce everything to the liberium arbitrium of the particular judge'. ${ }^{298}$ Of course 'judges must be governed by precedent in their function as law-makers, since otherwise there would be no law at all'.299 By the middle of the twentieth century, precedents supporting the recognition of a third category of obligations were, so far as he was concerned, already in place. The difficulty with his argument was that his interpretations of the precedents he had in mind - particularly Sinclair v Brougham were decidedly idiosyncratic.

The argument did, however, eventually take root. Wright had been dead nearly a quarter of a century before the House of Lords, in Lipkin Gorman v Karpnale, decided that the time had come 'for English law to recognise that a claim to restitution, based on the unjust enrichment of the defendant, may be met by the defence that the defendant has changed his position in good faith. ${ }^{3} 00$ That 'the law imposes an obligation on the recipient of stolen money to pay an equivalent sum to the victim if the recipient has been "unjustly enriched" at the expense of the true owner'301 had, according to Lord Templeman, been established by Lord Wright in Fibrosa when he spoke of how the 'remedies for ... unjust enrichment or unjust benefit' were ones which 'any civilized system of law is bound to provide'. ${ }^{302}$ In fact, as the Supreme Court of Canada had recognized in 1954,

294 Reading v Att.-Gen. [1951] A.C. 507, 513-514. The Lord Chancellor, Viscount Jowitt, apparently agreed: ibid 513 .

295 Orakpo v Manson Investments [1978] A.C. 95, 104 (decided 1977).

${ }^{296}$ R. Goff and G. Jones, The Law of Restitution (London: Sweet \& Maxwell, 1966).

${ }^{297} L E A$ xv.

${ }^{298}$ LEA 24, 25.

${ }^{299}$ LEA 391

300 Lipkin Gorman v Karpnale [1991] 2 A.C. 548, 558 per Lord Bridge, agreeing with Lord Goff, who delivered the main speech. "Whether change of position is, or should be, recognised as a defence to claims in restitution is a subject which has been much debated in the books', he observed. 'It is however a matter on which there is a remarkable unanimity of view, the consensus being to the effect that such a defence should be recognised in English law. I myself am under no doubt that this is right.... The time for its recognition in this country is, in my opinion, long overdue.' ibid 578, 580.

301 ibid 559 .

302 Fibrosa v Fairbairn, 61 
Wright was saying more than this. ${ }^{303}$ He was saying what the House of Lords was, in 1991, only just coming to accept: that remedies for unjust enrichment 'are generically different from remedies in contract or in tort, and are now recognized to fall within a third category of the common law ... [i.e.,] restitution. ${ }^{304}$

I shall draw this study to a close with an examination of one other, perhaps unexpected context in which Wright put his abilities as an innovative traditionalist to notable effect. But before doing so I want to examine a chapter in his judicial career which reminds us that his judgments were not always marked by boldness. The position Wright took on the protection of civil liberties in war-time can disappoint, and seem rather bewildering to, those who generally approve of his major judgments; it is certainly not one which would normally be espoused by a judge with a reputation for being progressive-minded. Whatever one makes of his position, I shall show, it is clear enough why he adopted it.

\section{K.'S OBSESSION}

When the responsibility for making certain categories of decision is taken away from courts and delegated to administrative tribunals, is this to be welcomed as an efficient dispersal of responsibility and an appropriate use of expertise, or is it to be condemned as a dangerous extension of the power of unaccountable bodies? Among Wright's lawyer contemporaries there was strong support for both arguments. 'The legislative practice of substituting for the jurisdiction of the Court that of a specially constituted tribunal is,' A. L. Goodhart wrote, 'well established and increasingly frequent'. ${ }^{305}$ So it should be, he believed, for it is simply cynical to think 'that there can be no law in the proper sense unless there is recourse to the Courts' and that 'executive officers have little respect for the law unless there is an appeal [sc., a right of appeal] to the Courts against their acts. ${ }^{306}$

Well-established and increasingly frequent the practice might have been, but this did not mean it was uncontroversial. In 1927 the Lord Chief Justice, Hewart, apparently lamented to the American Bar Association that there was in England 'a

\footnotetext{
303 See Deglman v Guaranty Trust Co. [1954] S.C.R. 725, 734, per Cartwright J. See also Corporation of the County of Carleton v Corporation of the City of Ottawa [1965] S.C.R. 663, 669 per Hall J.; and the decision by which the Court eventually recognized restitution as a distinct category of liability in Canadian law, Storthoaks v Mobil Oil Canada [1976] 2 S.C.R. 147, 163-164, per Martland J.

304 Fibrosa v Fairbairn, 61. Wright not only argued for the establishment of a legal category which was a long time coming in English law, but also conceived of the constructive trust as remedial - a position which is still to all intents and purposes rejected in England: see LEA 60 ('A constructive trust is imposed by the court irrespective of any intention to create it, and it is so imposed as a remedy to prevent unjust enrichment'); and cf. Re Polly Peck International plc (No. 2) [1998] 3 All E.R. 812, 830, C.A., per Nourse LJ ('[T] he remedial constructive trust gives the court a discretion to vary proprietary rights. You cannot grant a proprietary right to $\mathrm{A}$, who has not had one beforehand, without taking some proprietary right away from B. No English court has ever had the power to do that, except with the authority of Parliament').

305 A.L.G., Case Note (1942) 48 L.Q.R. 3, 7.

306 ibid 6-7.
} 
marked and increasing development of bureaucratic pretensions, the essence and aim of which are to withdraw more and more matters and topics from the jurisdiction of the court and to set them apart for purely official determination. ${ }^{3} 307$ Addressing English judges the following year, he re-cast the observation so that it was not so much a jeremiad as an expression of ironic disdain: with such bureaucratization 'there will be no judges at all...; the decision reached will not be open to appeal...; no party or other person interested will be permitted to appear or to offer evidence...; no lawyers will be tolerated except a group of advisers, departmentally appointed;... and the Lord Chancellor himself will have been exchanged for a Minister of Administration for whose office any knowledge of law, however slight, will be a statutory disqualification.'308 The observation would have raised as many eyebrows as chuckles. Although, in his famous book of 1929, Hewart effectively appointed himself England's severest critic of delegative legislation, ${ }^{309}$ at the time of the First World War he had been quite happy to see judicial functions transferred to the executive. ${ }^{310}$ Indeed, his disdain for delegative legislation turned out to be a passing phase: by the mid-1930s, he would re-assume a more relaxed position on administrative discretion, having come to the conclusion that civil servants needed law-making powers unencumbered by the possibility of judicial review if the welfare state was to survive. ${ }^{311}$

A more moderate voice in 1929, and in the long term a generally more consistent one, was that of C. K. Allen, Goodhart's predecessor as professor of jurisprudence at Oxford. '[W] are proud of our judges in England, and we have as good reason to be proud of our Civil Service', Allen observed,

[b]ut it is exactly from the executive officer's efficiency and zeal that we must save ourselves - and him. His business is to get things done ... and when principles of law are put in his way, he is apt to be impatient of them as mere pedantic obstructions.... [H]e is not the best person to be either legislator or judge, except under the close control of those who are trained to look beyond the practical means of obtaining an immediate object to the principles which may be involved in its attainment. ${ }^{312}$

This was not the first occasion on which Allen had felt moved to warn against the dangers of administrative discretion, ${ }^{313}$ and it would not be the last. For over thirty

\footnotetext{
307 As reported in R. W. Shannon, 'Bureaucracy and the Courts' (1930) 8 Can. Bar Rev. 77, 77.

308 Lord Hewart, 'His Majesty's Judges', in his Essays and Observations (London: Cassell, 1930) 121-123, 122-123.

${ }^{309}$ Lord Hewart, The New Despotism (London: Benn, 1929).

310 See R. Stevens, The Independence of the Judiciary: The View from the Lord Chancellor's Office (Oxford: Clarendon Press, 1993) 27; K. D. Ewing and C. A. Gearty, The Struggle for Civil Liberties: Political Freedom and the Rule of Law in Britain 1914-1945 (Oxford: Oxford University Press, 2000) 50.

311 See R. Jackson, The Chief: The Biography of Gordon Hewart, Lord Chief Justice of England, 1922-40 (London: Harrap, 1959) 216

312 C. K. Allen, 'Some Aspects of Administrative Law' (1929) 10 J.S.P.T.L. 10, 16-17.

313 See C. K. Allen, 'Bureaucracy Triumphant' (1923) 240 Quarterly Rev. 246; 'Bureaucracy Again' (1925) 244 Quarterly Rev. 38.
} 
years, he regularly wrote of how, in a democracy, it is unacceptable to place the executive above the law by removing the right of appeal from quasi-judicial tribunals. ${ }^{314}$ In his later years he wavered somewhat, coming around as he did to the view that according Parliament the power to delegate legislative capacity to administrative bodies will sometimes be a necessary expedient ${ }^{315}$ and that there has to be a number of 'minor exceptions' 316 to the general principle that administrative disputes should allow for a right of appeal. The premise from which he usually argued, nevertheless, was simple: 'the whole core theory of the balance of powers in our constitution', he wrote in 1945, is that 'restraint on power ... does not necessarily imply a deep suspicion of malevolent intentions' since ' $[t]$ he fact is ... that nobody on earth can be trusted with power without restraint. ${ }^{317}$

Not that Allen was particularly forthcoming in explaining precisely what was restraining the judges. ${ }^{318}$ Nor, in the long term, did many others share his general concern about the creeping bindweed of delegative legislation: by the time of his death in December 1966, the use of extra-judicial tribunals to resolve problems arising from the exercise of administrative powers had become an established feature of public life in Britain. ${ }^{319}$ But then the inevitable fact of the matter, as the opinions of Goodhart, Hewart and Allen illustrate, is that neither side of the delegative legislation debate had the advantage of a watertight argument.

Wright's contribution to the debate is typically commonsensical, if somewhat complacent. Parliamentary delegation of rule-making, prosecutorial and adjudicative powers to administrative tribunals is inevitable in these days of social, industrial and commercial legislation and control', he wrote in 1939, adding that 'the good sense of the English people will see that' such an arrangement 'is clearly convenient' and 'is fairly and properly worked. '320 There is no reason, he believed, that the common law should have any 'concern with these matters, except to see that the [tribunals'] statutory powers are not exceeded ... and ... that rights of individuals are not infringed beyond what the statute permits. ${ }^{321}$ Not only have we no need to worry about the erosion of the 'monopoly of judicial functions' 322 on the part of the courts - if the delegation of authority 'created abuses, modes of remedying them could be devised' 323 - but we ought positively to welcome the

\footnotetext{
314 See, e.g., C. K. Allen, Bureaucracy Triumphant (London: Oxford University Press, 1931); Democracy and the Individual (London: Oxford University Press, 1943); Law and Disorders: Legal Indiscretions (London: Stevens \& Sons, 1954); Administrative Jurisdiction (London: Stevens \& Sons, 1956).

315 See C.K. Allen, 'Law in the Making: Policy and Detail, The Provision of Safeguards' (letter), in The Times (16 March 1944) p.5.

316 C.K. Allen, 'Arbitrary Legislation' (letter), in The Times (20 Nov. 1951) p.5.

317 C.K. Allen, Law and Orders: An Inquiry into the Nature and Scope of Delegated Legislation and Executive Powers in England (London: Stevens \& Sons, 1945) 194.

318 He certainly did not seem convinced that it was stare decisis: see C. K. Allen, 'Precedent and Logic' (1925) 41 L.Q.R. 329, 333-334.

319 See T. Bingham, The Business of Judging: Selected Essays and Speeches (Oxford: Oxford University Press, 2000) 208.

320 LEA xxiii.

321 LEA 383.

322 LEA 194.

323 LEA 195.
} 
development, for the questions which occupy administrative bodies 'are in the main unsuited to decision by the ordinary process of law, partly because of the immense number of cases to be decided and partly because there are technical questions which can be easily decided by those who are expert in the matter, but which, if dealt with according to ordinary procedure of law, would require long and elaborate explanations to lay judges. ${ }^{3} 24$

To characterise the delegation of legislative and adjudicative powers as an exercise in 'despotism', Wright insisted in 1938, was simply 'inapt.'325 In despotic systems, '[n]o individual rights are secure against' the 'will of the despotic power' because ' $[t]$ here is no judicial machinery to declare, or at least to enforce, any individual rights against the State.' 326 The idea that the individual could ever be 'a nonentity as against the State' is simply 'not the English view.'327 Law in a democracy insists on 'government by the people, of the people, for the people'; it 'exists to regulate human life in the interests of justice'. 328 'The root ideas of English law' and 'the fruits and the nurturers of the British character' - to return to a passage quoted earlier - are, among other things, 'trial by jury, freedom from unlawful arrest or detention, ... freedom of speech'.329 '[T] hat the prisoner is innocent until he is proved to be guilty, and that the onus remains throughout on the prosecution' is one of the 'fundamental ideas of the common law', a basic 'principle of personal freedom,' which is 'too deeply ingrained in English ideas ever to be changed.'330 The despotic potential of delegated authority need not trouble us, for 'fundamental Common Law rights are, except in rare events, little interfered with'; that they should rarely be interfered with is perhaps inevitable, as such interference would be 'inconsistent with the true principles of democracy'.331

If interference with these common law rights is inconsistent with democratic principles, should not the conclusion be that, in a democracy, such rights must never be interfered with, rather than that they might be interfered with rarely or exceptionally? According to Sir John Laws, it is 'a condition of democracy's preservation' that there is recognized the validity of a 'higher-order law' incapable of being abrogated by statute, and epitomized by judge-made substantive principles of judicial review - by which courts can ensure that 'those who exercise democratic, political power must have limits set to what they may do ... which they are not allowed to overstep.'332 Yet when, in 2004, the Court of Appeal had to decide whether the threat of terrorism could override the right to freedom from executive detention, Laws LJ appeared to have sacrificed his notion of a higher-order law to '[t]he principle ... of proportionality,' according to which

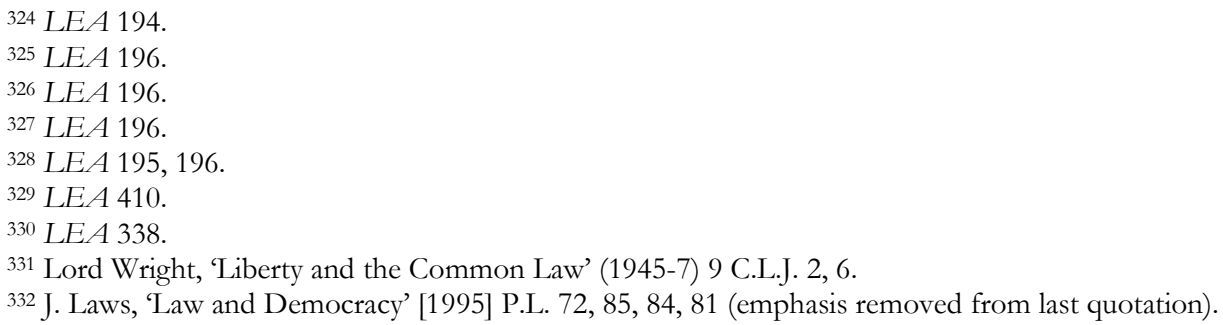


'the courts will expect the legislature to interfere with fundamental constitutional rights to the minimum extent necessary to fulfil the State's duty to safeguard its citizens and its own integrity. ${ }^{333}$ Wright, likewise, believed that a right may be fundamental yet, exceptionally, removable. Democracy obviously imposes constraints: 'the minority must be bound by the will of the majority expressed in constitutional form', indeed must be deemed 'to have consented to whatever constraints on freedom are constitutionally imposed. 334 The exceptions, in other words, will in effect be instances of self-binding: laws, enacted by democraticallyelected representatives, which deny a particular liberty to everybody. But even these exceptions, he insisted, are subject to constitutional requirements. '[T]he constitutional principles' and the 'necessary safeguards for the rights of a free people' are, first, 'that law should ... be made by Parliament, after full and open discussion in public, and then published authoritatively in statutes' and, secondly, 'that the rights of people should be determined by impartial Judges of the land, by judgment proclaimed in open Court after a public hearing'. ${ }^{335}$ But if parliamentary delegation of adjudicative authority has the effect of taking away basic individual basic liberties, can that delegation be justified constitutionally?

Wright, like Laws, concludes that sometimes it can be. In Barnard v Gorman, decided in 1941, a ship's steward suspected of smuggling sued the customs authorities for wrongful imprisonment after the case was dismissed by the magistrate. The House of Lords, reversing the Court of Appeal, was in no doubt that the authorities' action was justifiable according to s. 146 of the Customs Consolidated Act 1876, which provides that an 'offender may either be detained or proceeded against by summons'. To the steward's objection that the provision could not apply to him because he had not been shown to have committed an offence, Wright's answer was simple: to read the word 'offender' in s. 146 to mean only 'actual offender', and not to include the innocent person wrongly accused of the offence, would 'involve a manifest absurdity', for it would be to ignore the fact that ' $\mathrm{t}]$ he provision is clearly intended for the purpose of bringing the charge to investigation. ${ }^{336}$ This meant, of course, that the customs authorities had the power to detain innocent people. Wright recognized that this power sat uneasily with the principle 'that the liberty of the subject is to be duly safeguarded', but he considered it constitutionally justifiable because the legislature had expressed its intention that 'powers of arrest beyond those existing at common law should not be too narrowly construed. ${ }^{337} \mathrm{He}$ may have sounded high-minded about fundamental common-law rights, but he did not believe that the courts should always have the last word when it came to the protection of civil liberties.

Nowhere is this more evident than in Liversidge $\mathrm{v}$ Anderson, the case in which

${ }_{333} \mathrm{R}$ (Abu Rideh) v Secretary of State for the Home Department [2004] EWCA Civ. 1123, [1234]. Laws and Pill LJJ were the majority (Neuberger LJ dissented in part). The decision was overruled by the House of Lords: A v Secretary of State for the Home Department [2005] UKHL 71.

334 LEA 195-196.

335 Lord Wright, $\mathrm{n} 331$ above, 6.

336 Barnard v Gorman [1941] A.C. 378, 391.

337 ibid 389. 
the majority of the House of Lords decided that a minister had the power to order detention without either a warrant or the judgment of a court if he had - to quote the words of regulation 18B of the Defence (General) Regulations 1939 'reasonable cause to believe any person to be of hostile origin or associations or to have been recently concerned in acts prejudicial to the public safety or the defence of the realm ....' The case is best remembered today for Lord Atkin's lone dissent, in which he argued that the term 'reasonable cause' had to be construed 'as an objective fact' 338 - that a court is entitled to look for evidence as to the reasonableness of the minister's belief - if it were to mean anything other than that a person should be detained because a minister believes he should be detained.

Atkin did not mince his words. 'I view with apprehension the attitude of judges who on a mere question of construction when face to face with claims involving the liberty of the subject show themselves more executive minded than the executive.... In this case I have listened to arguments which might have been addressed acceptably to the Court of King's Bench in the time of Charles I.... The words [in regulation 18B] have only one meaning.... They have never been used in the sense now imputed to them.... I know of only one authority which might justify the suggested method of construction: "When I use a word," Humpty Dumpty said in a rather scornful tone, "it means what I choose it to mean, neither more nor less." 339 There was considerable public enthusiasm, and also some support in the law journals, for what Atkin had to say. ${ }^{340}$ But his opponents seem for the most part to have been furious with him. Apparently various peers, including Wright, ostracized Atkin after the case was decided, 341 and one of them wrote to The Times publicly criticizing his dissent. ${ }^{342}$ Goodhart, writing in his capacity as Editor of the Law Quarterly Review, implied that Atkin was arrogant, 343

\footnotetext{
338 Liversidge v Anderson [1942] A.C. 206, 228 (hereafter Liversidge). 339 ibid 244-245.

340 On public support, see e.g. Anon., 'Parliament \& Home Secretary's Powers: "Reasonable Cause" under 18B' Manchester Guardian (8 Nov. 1941) p.7; H.J. Laski, 'Property, Justice \& Gentlemen' Reynolds News (16 Nov. 1941) p.2 ('Lord Atkin's dissent in Liversidge v Anderson represents the settled conviction of every citizen who understands the tradition of public liberty'); R. F. V. Heuston, 'Liversidge v. Anderson in Retrospect' (1970) 86 L.Q.R. 33, 52-53. For support in the law journals see, e.g., G. W. Keeton, 'Liversidge v. Anderson' (1942) 5 M.L.R. 162; C. K. Allen, 'Regulation 18B and Reasonable Cause' (1942) 58 L.Q.R. 232.

341 One of Atkin's daughters, Elizabeth Cockburn Millar, accompanied Atkin to the House of Lords to hear him deliver his judgment. In an unpublished, undated, one-page typescript, 'Liversidge v. Anderson', held at Gray's Inn Library (ATK1/JUD/2/2/3), she recalls that afterwards '[m]y father took me with him to the Dining Room and we sat at a table together. Wright, I know, passed us by without a word - as he was a very old friend and a visitor to our house, this was strange but I think perhaps my father knew he was going to be unpopular.'

342 See 'War and Habeas Corpus. The Arguments in Court: Lord Maugham's Comment' (letter), in The Times (6 Nov. 1941) p.5; also Lord Wright to A. L. Goodhart, 22 Nov. 1941, in Goodhart papers, Bodleian (Special Collections), MS Eng. c. 2891 ('It was a pity Maugham wrote to the Times. He should at least have consulted us [the other Lords of Appeal who were in the majority?] and the L[ord] C[hancellor]').

343 A. L. G., Case Note (1942) 58 L.Q.R. 3, 6-7.
} 
alleged that he was inconsistent ${ }^{344}$ and, bizarrely, observed that if any jurist had done as Atkin had done and described the majority in Liversidge as more executiveminded than the executive, they could have been held in contempt of court. ${ }^{345}$ In a private communication to Goodhart, Wright described Atkin's action as 'pure impudence'. ${ }^{346}$

Although academic lawyers today, even those who argue forcefully for the protection of civil liberties, can be markedly unenthusiastic about Atkin's dissent, ${ }^{347}$ it seems fair to say that in law his position has prevailed. ${ }^{348}$ By contrast, Wright - who was among the majority in Liversidge - adopted a position that is now discredited. ${ }^{349}$ Not that the stance that he took was unfashionable when the case was decided. When Sir William Holdsworth died in 1944, Wright remembered him with affection - they 'met as fellow lecturers at the London School of Economics'350 - and wrote of him as a like-minded soul: he had shared

344 ibid 7-8. As a judge of the King's Bench Division during World War I, Atkin had concurred in a decision to suspend habeas corpus because of the power delegated to the Home Secretary by regulation 14B of the Defence of the Realm (Consolidation) Act 1914: see Lipton v Ford [1917] 2 K.B. 647, 654; also R v Halliday, ex p. Zadig [1917] A.C. 260, H.L.. Goodhart omits to mention that Atkin's position on the liberty of the subject had changed long before Liversidge: see 117 Parl. Deb., H.L. col. 23 (30 July 1940) ('My Lords, I am bound to say that, looking at this Bill [the Emergency Powers (Defence) (No. 2) Bill] and nothing but this Bill, I shared the anxiety which I know has been felt by a great many people interested in the administration of criminal justice at the unlimited powers, without any express safeguards, that are given to the government in this matter; because I imagine it is quite without precedent for Parliament to confide to the Executive the power to create new Courts with powers of life and death without there being any provision at all qualifying the nature of the jurisdiction'); and Eshugbayi Eleko v Officer Administering the Government of Nigeria [1931] A.C. 662, 670, P.C. ('In accordance with British jurisprudence no member of the Executive can interfere with the liberty of property of a British subject except on the condition that he can support the legality of his action before a court of justice. And it is the tradition of British justice that judges should not shrink from deciding such issues in the face of the Executive').

345 See A. L. G., Case Note (1942) 58 L.Q.R. 3, 8.

346 Lord Wright to A. L. Goodhart, n.d., in Goodhart papers, Bodleian (Special Collections), MS Eng. c. 2891.

347 See, e.g., A. W. Brian Simpson, In the Highest Degree Odious: Detention without Trial in Wartime Britain (Oxford: Clarendon Press, 1992) 363; Ewing and Gearty, n 310 above, 397.

348 See, e.g., Nakkuda Ali v Jayaratne [1951] A.C. 66, 76-77 per Lord Radcliffe; IRC v Rossminster [1980] A.C. 952, 1011 per Lord Diplock ('The time has come to acknowledge openly that the majority of this House in Liversidge v. Anderson were expediently and, at that time, perhaps excusably, wrong and the dissenting speech of Lord Atkin was right'); R v Home Secretary, ex p. Khawaja [1984] A.C. 74, 110 per Lord Scarman ('The classic dissent of Lord Atkin ... is now accepted as correct not only on the point of construction of regulation 18(b) of the then Emergency Regulations but in its declaration of English legal principle'); Bingham, The Business of Judging, 220 ('... Lord Atkin was correct in his essential argument on the meaning of the words used in ... Regulation $18 \mathrm{~B} \ldots .$. I think that the majority were right, in fact if not in law, in concluding that it was the subjective and not the objective test which those who framed the Regulation, and Parliament, intended.... In the sense much more important than the narrow legal sense, however, Lord Atkin has been proved to be triumphantly correct'); J. Steyn, 'Guantanamo Bay: The Legal Black Hole' (F. A. Mann lecture, 23 Nov. 2003), www.statewatch.org/news/2003/nov/guantanamo.pdf (visited 18 Dec. 2008) at 1 ('Lord Atkin's view on the interpretation of provisions such as Regulation 18B has prevailed: the Secretary of State's power to detail must be exercised on objectively reasonable grounds').

349 See, e.g., D. Clark and G. McCoy, The Most Fundamental Right: Habeas Corpus in the Commonwealth (Oxford: Clarendon Press, 2000) 100-101; D. Dyzenhaus, The Constitution of Law: Legality in a Time of Emergency (Cambridge: Cambridge University Press, 2006) 154.

${ }^{350}$ Lord Wright, 'Sir William Searle Holdsworth, Kt., O.M., K.C., D.C.L., 1871-1944' (1944) 60 L.Q.R. 139, 139. Holdsworth's A History of English Law, vol. 12 (London: Methuen, 1938) is dedicated to Wright 'in memory of the days when he and the author both taught law at London University' (p.v). 
Wright's 'profound belief in 'principles of justice and freedom which have always been, and still are, too deeply rooted in the English temperament ever to be superseded. ${ }^{351}$ But not all lawyers considered Holdsworth and Wright united by devotion to the common law as a bastion of liberty. At the beginning of 1942, the Law Quarterly Review had opened with a note by Holdsworth defending the decision in Liversidge on the basis that 'the clearest and most logical'352 explanation of why the requirement of reasonable cause under regulation 18B involved only a subjective test had been provided by Wright. G. W. Keeton, writing in the Modern Law Review, was flummoxed: Holdsworth's position, and of course by extension Wright's, 'is comprehensible only on the hypothesis that under [emergency powers legislation] the judiciary abdicates completely in favour of the executive. If this is the position, then the distinction between our present constitution and that of any Continental "police state" is reduced to vanishing point."353 Wright would have wholeheartedly rejected this proposition. So what, in Liversidge, was he arguing?

His starting-point is Edmund Burke. 'I flatter myself that I love a manly, moral, regulated liberty', Burke wrote, but he appreciated that absolute liberty, 'stripped of every relation, in all the nakedness and solitude of metaphysical abstraction', is an absurd ideal: '[a]m I to congratulate an highwayman and murderer, who has broke prison, upon the recovery of his natural rights?'354 The liberty of the subject, according to Wright, 'is a liberty confined and controlled by law, ... in Burke's words, a regulated freedom. ${ }^{3355}$ Wright maintained that his 'prejudices' were 'in favour of upholding the liberty of the subject', but that 'in the constitution of this country there are no guaranteed or absolute rights' and that Liversidge raised one of those exceptional instances where fundamental rights had to be interfered with, the 'safeguard' against unwarranted interference being 'the good sense of the [British] people and ... the system of representative and responsible government which has been evolved.'356 About the fact that regulation $18 \mathrm{~B}$ excluded the jurisdiction of the courts Wright seemed no less complacent: like Goodhart, he noted that ' $[\mathrm{i}] \mathrm{n}$ ordinary administrative measures, the ... practice ... is well established and increasingly frequent', ${ }^{357}$ though he also followed Goodhart in omitting to say anything about the furore that the practice had generated.

For Wright, however, the good sense of the people and the fact that it was not uncommon for Parliament to delegate judicial powers to administrative bodies do not provide sufficient reason to conclude that the detention order challenged in Liversidge was valid. That it indeed was valid is explicable primarily, he argued, by the fact that the matter to be decided under regulation $18 \mathrm{~B}$ - whether a person is of hostile origin or associations - is not one which can be satisfactorily settled by a

\footnotetext{
351 Lord Wright, ibid 146.

352 W. S. Holdsworth, Case Note (1942) 58 L.Q.R. 1, 1.

353 Keeton, n 340 above, 173.

354 E. Burke, Reflections on the Revolution in France, And on the Proceedings in Certain Societies in London Relative to that Event, ed. C. C. O’Brien (Harmondsworth: Penguin, 1968 [1790]) 89-90.

355 Liversidge, 260.

356 Liversidge, 261.

357 Liversidge, 264.
} 
court. ' $[\mathrm{N}] \mathrm{o}$ tribunal could be imagined less appropriate than a court of law for deciding' such a matter, Wright insisted, because 'a judge ... cannot possibly have the full information on which the minister has acted or appreciate the full importance in the national interest of what the information discloses', not least because ' $[t]$ o a large extent the sources of information must be kept secret.' 358 As to the claim that the requirement of reasonable cause required proof of an objective fact, Wright just could not see it: of course "[t]he word "reasonable" implies 'intelligent care and deliberation' - the minister 'must be reasonably satisfied before he acts' - but the choice 'is still his decision and not the decision of anyone else', just as when 'I say that I reasonably believe in the truth of certain facts ... I am prima facie adopting my reason as my judgment.' ${ }^{359}$ If the minister 'believes that he has in his own mind what he thinks is reasonable cause' to detain, then his 'duty ... in the national interest' is to act on this belief. 'That is a higher duty than the duty to regard the liberty of the subject.' 360

'[T]he minister', Wright insisted, 'must not lightly or arbitrarily invade the liberty of the subject', 361 though it was unclear why this stipulation was to be taken seriously if reasonable cause was simply what the minister 'thinks is reasonable cause.' Before delivery of judgment in Liversidge the then Lord Chancellor, Viscount Simon, had suggested to Lord Atkin that he might consider removing the reference to Humpty Dumpty from his speech. ${ }^{362}$ It seems obvious, in the light of Wright's reasoning, why Atkin would have considered the reference apt. For three reasons, however, Wright considered it simplistic to conclude that regulation $18 \mathrm{~B}$ conferred an unfettered power. First, judges could still be called on to examine ministerial decisions under regulation $18 \mathrm{~B}$ where a complainant was alleging dishonesty, mistaken identity or some other matter falling within the proper remit of a court. ${ }^{363}$ Secondly, a minister exercising emergency powers had in any event 'to report to Parliament at least once a month as to the action he has taken' - hardly 'a very effective check' on his discretion, Wright conceded, but still one which could be 'sufficiently felt in the Press and in Parliament' if 'the country was outraged by the system or practice of making detention orders'. ${ }^{364}$ Thirdly, there had been established in 1939 a specialist committee to advise the Home Secretary on cases of detention under the emergency powers; although this committee's advice 'did not bind the Secretary', Wright recalled in 1946 - there was, in fact, no actual requirement that its advice be sought - the existence of the committee had apparently been significant in convincing the majority in Liversidge

\footnotetext{
${ }^{358}$ Liversidge, 266

${ }^{359}$ Liversidge, 268.

${ }^{360}$ Liversidge, 265.

361 Liversidge, 268.

362 See Heuston, n 340 above, 43-44.

363 See Liversidge, 261. In Greene v Secretary of State, decided by the House of Lords on the same day as Liversidge was decided, Wright took the view that where a complainant is called to appear before a committee to hear the reasons supporting his detainment and those reasons are incorrectly stated in the detention order, he should be given an opportunity for a further hearing before a differently-constituted committee: see Greene v Secretary of State for Home Affairs [1942] A.C. 284, 300.

${ }^{364}$ Liversidge, 270.
} 
of 'the strength of the Government's case'. ${ }^{365}$

On Atkin's death in 1944, Wright remembered him as a judge who 'in no Workmen's compensation case' decided 'against the workman.' ${ }^{366}$ In these cases Wright himself, we have seen, was similarly capable of assuming the perspective of the more vulnerable party. But one could never say that they shared the same attitude towards the protection of civil liberties. In Liversidge, C. K. Allen thought, Wright seemed indifferent to the vulnerable party; he seemed to spare no thought for 'the individual who is languishing in prison for weeks or months together, without trial, without even knowledge of the charge against him, and without any redress whatsoever'. ${ }^{367}$ Wright considered Allen wrong. ${ }^{368}$ Real vulnerability, so far as Wright was concerned, is to be located elsewhere. His view was fundamentally Hobbesian: the state exists to secure peace, and when there is a conflict between the freedom and the protection of citizens, protection prevails. ${ }^{369} \mathrm{He}$ understood that when governments detain suspects without trial there is a risk that the rights of some innocent people may be denied, but he considered such detentions justifiable - notwithstanding that an unintended side-effect may be the imprisonment of innocent civilians - if an enemy poses a serious threat to national security or civilian lives.

This thinking is not out of line with what we find affirmed in many modern human rights documents. ${ }^{370}$ What makes Wright's position - the position taken by the majority in Liversidge - controversial is not the insistence that governments may set aside human rights in the event of some serious threat to security, but that they may do so without the possibility of their decisions being reviewed by the courts. About this, we have seen already, Wright was adamant: the task of protecting citizens in times of emergency is one to which the government, with its privileged access to intelligence information, is eminently better suited than the courts could ever be. Not only, he insisted, did the majority of the House of Lords in Liversidge understand this - they relinquished their decision-making function so that the court could be 'the ally of Parliament' in 'the fight against autocracy'371 - but so too did the British people, who were willing to bear 'acts of interference, restriction and control, because they trust the Government to do what is best to save the country. ${ }^{372}$ This trust is sensible and appropriate, he believed, because the government acts for the people, and has every incentive not to do otherwise: 'a living, free and instructed democracy ... can always, at least in the long run, make its voice felt. It is not merely that the people choose who are to be the ministers

\footnotetext{
365 Wright, 'Atkin' (P.B.A.) 319.

366 Wright, 'Atkin' (L.Q.R.) 334.

367 Allen, n 340 above, 236.

368 'I think C. K. Allen was completely in error; I do resent his attacks on us and other judges who dared to differ from him. I have never known anything like it.' Lord Wright to A. L. Goodhart, 22 Nov. 1941, in Goodhart papers, Bodleian Library (Special Collections), MS Eng. c. 2891.

369 See Hobbes, Leviathan, II. xxi. 21.

370 See James Griffin, On Human Rights (Oxford: Oxford University Press, 2008) 59-60.

371 Lord Wright, n 350 above, 146.

372 Lord Wright, n 331 above, 15.
} 
who govern; it also, at least on big issues, subtly and indirectly makes its desires and purposes known and effective. A government must have regard to them or it cannot continue, but must give place to others. ${ }^{373}$

\section{THE TOTALITARIAN CRIME AGAINST PEACE}

For Wright, then, if law is to be used effectively in the fight against tyranny, it is important that we are willing to retreat somewhat from our ideals and accept that the exigencies of war may make it preferable that a politician rather than a judicial panel has the last word regarding the liberty of an individual. Retreating thus does not mean riding roughshod over civil liberties or treating the individual as a nonentity as against the state, because freedom is compromised only to the extent required to protect the interests of justice. Indeed, it is precisely because the common law seeks, through its principles, to uphold justice that liberty is maintained. 'The Common Law ... has, so far as I know, never flourished except in nations which are free, and I don't believe it can be received by any nation until that nation has come into full enjoyment of liberty', Wright proclaimed in 1936, because the '[1]aw is the spirit of fairness and justice.... It is the antithesis of greed and brute force $\ldots$ of autocracy and tyranny. ${ }^{374}$ The rhetoric conceals a familiar motif which epitomizes Wright's innovative traditionalism: the decision that a court makes, including a decision not to interfere with the decision-making powers of other bodies, must seek to achieve what any fair and reasonable person would recognize to be justice along the lines of established legal principle. This does not preclude the possibility of fair-minded people disliking a court's effort to manipulate a principle for a particular purpose - it might be said that Wright was manipulating a principle in Liversidge when he argued that, while liberty under the common law is a fundamental right, this liberty cannot be genuine if liberty is never regulated - but it does mean that it is inappropriate for a court to decide on grounds that fair-minded people would find unintelligible.

Wright's argument entails the assumption that one can understand justice as an objective concept: justice must be justice according to law, and doing justice according to law includes not only the straightforward application of established authorities but also the imaginative interpretation or distinguishing of authorities in such a way that the modification of a legal principle makes sense to, even if it will not always meet with the approval of, reasonably-minded people. But what is this 'justice' that is to be done according to law? '[T] here are almost infinite variations in the conception of what is just', Wright's colleague, Lord Macmillan,

\footnotetext{
373 ibid 16.

${ }^{374}$ Lord Wright, 'The World's Greatest Need Today is Law' (1936) 22 A.B.A.J. 722, 723.
} 
observed. 'It is indefinable, like all the greatest things in life.'375 Wright's explanation of the concept was hardly more precise:

I have not found any satisfactory definition of justice, but whatever it is, it is the quality of what is just. And what is just in any particular case is what appears to be just to the just man, in the same way as what is reasonable is what appears to be reasonable to the reasonable man. ${ }^{376}$

That justice is a 'quality', Wright added, is evident from the fact that we are often convinced that "the word "just" seems an inappropriate epithet to apply"377 to certain actions and states of affairs, possibly because the situation which confronts us arouses a sense of injustice. This supplementary observation takes us no closer to understanding justice itself, however, and indeed were this study of Wright to conclude near the end of World War II one of its conclusions would be that he considered it important that judges innovate in the cause of justice but that he had nothing to say about justice itself other than that judges must pursue it within the framework of established law.

After the War, however, his conception of justice changed. As a barrister specializing in prize court jurisdiction during World War I, Wright had been aware of the ruthlessness with which the German forces would capture and condemn non-military vessels belonging to the enemy. ${ }^{378}$ During World War II, he had been struck by the similarly ruthless manner in which Germany had treated its own innocent civilians. Of course, he observed, civilians 'may lose their lives ... if they come within the deadly range of manoeuvres', but this does not make it permissible 'deliberately to take and kill the innocent non-combatant'; such action invokes 'the profound aversion of humanity', and it is certainly 'contrary to the law of war' to use 'non-combatant men, women, and children ... as a screen against the enemy'. ${ }^{379}$ Yet Germany alone, Wright asserted, had flouted this law: 'no nation other than Germany has resorted to the killing of members of the population to secure peace and order. ${ }^{380}$ It was his inability to comprehend

375 Lord Macmillan, Law \& Other Things (Cambridge: Cambridge University Press, 1937) 13, 281.

376 LEA 382.

377 LEA 382-383.

378 See Goodhart, $\mathrm{n} 7$ above, 435-436.

${ }^{379}$ Lord Wright, 'The Killing of Hostages as a War Crime' (1948) 25 British Yearbook of International Lam 296, 300-301. See also Lord Wright, 'Foreword', in United Nations War Crimes Commission, Law Reports of Trials of War Criminals, 15 vols (London: HMSO, 1949) at VIII, pp.vii-xi at viii ('I have felt that a decision that one may slaughter innocent hostages so long as the number slaughtered is not excessive, even subject to the pre-conditions specified in the judgment, is retrograde, and is in my opinion contrary to the general course of humanitarian jurisprudence in regard to warfare which has been developed up to the present') and xi ('to claim to kill innocent non-combatants by calling them hostages is contrary to the whole spirit of the movement to protect non-combatants as far as may be from the evils of war').

380 Wright, 'The Killing of Hostages as a War Crime', ibid 304. This was not, he argued after the War, a reason to bear a grudge. 'The British at least are poor haters. Britain has not been occupied or conquered. Memories are short. Immediate problems and necessities crowd out thought for what is past. The idea of retributive justice becomes cold and repelling.' Lord Wright, 'Foreword', in United Nations War Crimes Commission, Law Reports of Trials of War Criminals, 15 vols (London: HMSO, 1947) at II, pp.ix-xii at x-xi. 
German behaviour in war-time which apparently led him in 1944 to accept the post of Australia's representative on the United Nations War Crimes Commission. ${ }^{381}$ The following year he became the Commission's chairman. ${ }^{382}$

The object of the War Crimes Commission was to collect material on which to base the charges at the Nuremberg trials. During their inquiries Wright, by now in his late seventies, and other members of the Commission visited Germany and inspected the camps where the worst crimes had been perpetrated. (Wright would also fly to Japan to attend the Tokyo Military Tribunal.) The Commission performed its duties carefully and the Nuremberg Tribunal acknowledged how valuable its assistance had been; for the work that he had done, Wright himself was in 1948 appointed a G. C. M. G., an order of chivalry used to honour individuals who have rendered special services to foreign nations. ${ }^{383}$ The work clearly made a deep impact on Wright. In the mid-1940s, he began writing about international law in the aftermath of the atrocities that had been committed. The ensuing essays, the last significant ones he would ever produce, show that the wartime actions of the Germans and their allies stirred within him strong feelings and inspired him to explain his commitment to justice with rather more care and effort than is evident in his earlier musings on the topic.

The German legal philosopher, Gustav Radbruch, became a natural lawyer, it is sometimes said, because of his experience of the Third Reich. ${ }^{384}$ We cannot be sure to what extent, if at all, Wright was predisposed to natural law arguments before World War II - there are certainly hints that such arguments were already on his mind ${ }^{385}$ - but there is no doubt that his experiences as Chairman of the War Crimes Commission moved him to conceive of international law and justice in explicitly natural law terms. In 1938, he had written of how the principle of 'comity of nations' requires that states do not interfere with one another's legal arrangements. ${ }^{386}$ But 'the incredible and unspeakable atrocities committed by the Germans and their allies during the course of the war' 387 made him reassess his

\footnotetext{
381 See Goodhart, $n 7$ above, 436.

382 On Wright in this role, see A.J. Kochai, Prelude to Nuremberg: Allied War Crimes Policy and the Question of Punishment (Chapel Hill, NC: University of North Carolina Press, 1998) 127-137, 201-203.

383 See Anon., 'Lord Wright: Former Lord of Appeal', 15.

384 See, e.g., L.L. Fuller, 'American Legal Philosophy at Mid-Century' (1954) 6 J. Legal Educ. 457, 481-483; H. L. A. Hart, 'Positivism and the Separation of Law and Morals' (1958) 71 Harv. L. Rev. 593, 616-618. The assumption that Radbruch underwent, as a Hart puts it, a 'conversion' (ibid 616) may be an oversimplification: see S.L. Paulson, 'Radbruch on Unjust Laws: Competing Earlier and Later Views?' (1995) 15 O.J.L.S. 489.

385 See Lord Wright, 'Introduction', in P. W. Thayer, Cases and Materials in the Law Merchant (Cambridge, Mass. Harvard University Press, 1939) xi-xxi, xi-xii ('Sir Frederick Pollock [said] that the Law Merchant was a species of natural law... [W] hat I think was meant was that Commercial law in its early stages was not a product imposed by an outside authority, either Parliament or Judge.... It was evolved empirically in order to meet the practical exigencies which emerged in the actual day-to-day conduct of business[,] ... the spontaneous product growing naturally (as it were) out of the experiences and needs of merchants'); also J. M. Finnis, 'Developments in Judicial Jurisprudence' (1962) 1 Adelaide L. Rev. 317, 336 (drawing attention to Wright's argument that contracts be interpreted on the basis of what is just and reasonable). 386 LEA 173; see also Compania Naviera Vascongado v S.S. Cristina [1938] A.C. 485, 502.

387 Lord Wright, 'Natural Law and International Law', in P. Sayre (ed), Interpretations of Modern Legal Philosophies: Essays in Honor of Roscoe Pound (New York: Oxford University Press, 1947) 794-807, 794.
} 
position. 'The crimes and atrocities committed by the Axis powers', he observed in a radio broadcast in November 1946,

are beyond anything in history both in regard to their range and enormity. They are international in character and are to be judged according to rules of international law. I should think very ill of international law if it provided no means of punishing such crimes. The demands of the civilised nations for the trial and punishment [of the perpetrators] ... was motivated by the deep and universal sense of humanity that such actions should not escape their just punishment. $^{388}$

If the 'primary purpose' of law is 'the quest of justice', 389 justifications must be found for punishing the malefactors who perpetrated these atrocities. Wright appreciated that those who sought to be exonerated could, in the courtroom, mount a variety of legal arguments in their defence: in particular, that they were acting on superior orders, that heads of state were immune from prosecution, that the laws of war as set out in the Hague Convention bound nations rather than individual wrongdoers, and that punishment depended on the application of laws which are vague or relied on retrospectively - the nulla poena sine lege defence - so that the alleged violators cannot be taken to have known that what they were doing was against the law. ${ }^{390}$ None of these defences impressed him. One cannot hide behind a superior order, he argued, if following the order meant committing a crime; diplomatic immunity is a 'reciprocal courtesy' between nations which 'no longer continues in war conditions'391; it would be 'strange and illogical' if the Hague Convention left the punishment of those individuals whose crimes were committed on behalf of their nation in the hands of their national courts ${ }^{392}$; and a criminal certainly 'cannot exculpate himself on the grounds that he was ignorant of the law which affects him. ${ }^{3} 93$

Others, Wright felt, had done a good job of discrediting these defences. ${ }^{394}$ The pressing task as he saw it - as he was perhaps bound to see it, given his innovative-traditionalist outlook - was to show how the perpetrators of atrocities could be punished according to existing legal authority. The Kellog-Briand Pact of 1928 , he argued, 'was ... the culmination of a long series of efforts to outlaw aggressive war and to make it a crime', and is properly interpreted as 'constitut[ing] a positive law of equal validity with the Laws of War.'395 Although the Pact stipulated 'no sanctions' against aggressor nations, and provided no terms for

\footnotetext{
388 Lord Wright, 'The Meaning of Nuremberg', typescript of BBC radio broadcast, 22 Nov. 1946, 4pp., at p.1, in Goodhart papers, Bodleian (Special Collections), MS Eng. c. 3113.

389 Wright, n 387 above, 794.

390 See ibid 796-797; Lord Wright, 'War Crimes under International Law' (1946) 62 L.Q.R. 40, 44-46.

${ }^{391}$ Lord Wright, 'War Crimes under International Law', ibid 45.

392 Wright, n 387 above, 796.

393 Lord Wright, 'War Crimes under International Law', n 390 above, 44.

394 See, e.g. ibid 44, 48.

395 Lord Wright, 'Nuremberg' (Fall 1947) 22 Obiter Dicta (Osgoode Hall) 14-20, 18.
} 
disarmament or 'machinery ... for the settlement of differences between nations', it nevertheless made it clear that the instigation of war 'is an illegal thing' and that 'the heads of the State who bring about the war are by their acts personally guilty of doing what the Pact declares to be illegal.'396 To punish 'crimes against peace' which was one of the counts listed in the indictment presented to the International Military Tribunal at Nuremberg in 1945 - is, he insisted, to do justice according to law', 397 and so, notwithstanding that trials of war criminals may present peculiar evidentiary and other problems, there is, in principle, no reason that an international military court should not proceed with such trials.

Wright appeared to be glossing over some crucial matters of detail in order to make his argument look convincing. ' $\mathrm{f} \mathrm{f}$ there is International Law at all,' he claimed, 'I can see no reason of logic or common sense why it should not be taken to create rights in favour of or obligations binding upon particular individuals. ${ }^{3} 98$ But he seemed to be putting the argument the wrong way around. Would not rights and obligations have to be created in order for there to be international law? What of the absence of particular sanctions attaching to, and specific machinery for the enforcement of, international agreements? Wright did not explain but simply asserted - albeit correctly 399 - that sanctions are not a necessary condition for the existence of law. 'I should not agree that there cannot be an International Criminal Law unless there is a code of punishments attached to it', because ' $[t]$ he coercive element of the law may be merely moral. ${ }^{400}$ The justification for the imposition of a punishment may be that the behaviour in question is intrinsically bad when judged by 'the principles of logic of morality and of the conscience of civilized mankind'. ${ }^{401}$ Whether it be a judge or anyone else imagining themselves as the recipient of that behaviour, they would recognize it to be, and would want it to be treated as, evil.

The law, then, should punish those actions which are self-evidently contrary to 'the innate sense of right and wrong possessed by all decent-minded human beings.' ${ }^{402}$ Wright understood that in arguing thus he was 'introduc[ing] the concept of natural law'403 as the 'ultimate justification'404 for the legal decision. Rather than offering his own explanation of the concept of natural law, he quotes with approval a French natural lawyer, Félix Senn, who asserts that it is crucial to

\footnotetext{
${ }^{396}$ Lord Wright, 'War Crimes under International Law', n 390 above, 50-51.

397 ibid 49.

398 Wright, n 387 above, 803.

399 Because law has purposes other than the regulation of recalcitrance. It may make sense to recognize the authority of rules co-ordinating particular pursuits, for example, not because they are backed by sanctions (though they may well be) but because they enable certain forms of human interaction to be conducted with precision and predictability. These rules would be necessary even in a society where recalcitrance was absent and sanctions therefore otiose. See J. Finnis, Natural Law and Natural Rights (Oxford: Clarendon Press, 1980) 267-269.

400 Wright, n 387 above, 805.

${ }^{401}$ Lord Wright, 'War Crimes under International Law', n 390 above, 52.

402 Lord Wright, 'Introductory Chapter', in United Nations War Crimes Commission, History of the United Nations War Crimes Commission and the Development of the Laws of War (London: HMSO, 1948) 1-23, 16.

403 Wright, n 387 above, 802.

404 Wright, 'The Killing of Hostages as a War Crime', n 379 above, 305.
} 
human survival ' $t$ ] hat man does not forget that he is a reasonable animal living in society', that he 'complies with the laws of generation and conservation of the species,' that he remains religious, that he maintains his devotion (pietas) to his family and his home-land, that he accepts as goods knowledge, truth, regard for others and their property and 'respect for the pledged word'. ${ }^{405}$ Since these goods 'are naturally designed for life in society,' Senn continues, 'men who violate these laws, precepts, givens, notions of life and shared community will isolate themselves; forming thoughts and acting contrary to even their own nature, they will destroy any society. Such is the lesson, precise and devastating, that the tradition transmits in diverse languages through the centuries. ${ }^{306}$ The instigation of war, Wright argued, is 'an evil thing', ${ }^{407}$ a choice incompatible with these goods, with 'the laws of humanity and the dictates of public conscience.'408

One must not make the mistake, he insisted, of thinking that natural law, thus understood, is 'something ... above and behind the majesty of the positive law.'409 Natural law, rather, is bound up with the positive law; they 'join hands.' 410 So it is that he squares his turn to natural law with his innovative-traditionalist approach to the solution of legal problems. For support for the proposition that positive law and natural law exist complementarily, one might look first of all, he argues, to François Gény and the French wing of the Free Law movement. ${ }^{411}$ For Gény, judges have the power and the responsibility not to decide cases in any way they think fit but to act as interstitial legislators, bridging the gaps left between the words of formal legal texts. If judges are to bridge such gaps then, Gény insisted (citing contemporaries who argued '[i] $\mathrm{n}$ favour of a return to natural law concerns'), they must not simply rely on their own instincts as to what the law ought to be, but 'should take into account the inspirations of reason and conscience in order to examine the mystery of good [juste]."412 The parallel of this approach could be found, Wright thought, in the English courts' application of principles of natural justice 'to supplement the statutory law'. ${ }^{413}$ Perhaps the best evidence of the connection between natural and positive law is the common law itself: the 'English lawyer ... knows that the early development of English law may be said without any serious inaccuracy to have proceeded on the basis of natural law... [E]quity was created on the basis of natural law or justice.... It is with these and other like considerations in mind that an English lawyer approaches the proposition that there cannot be an International Law affecting individuals. ${ }^{314}$

\footnotetext{
405 F. Senn, De la justice et du droit: Explication de la définition traditionnelle de la justice (Paris: Sirey, 1927) 85-86.

406 ibid 86-87. See Wright, n 387 above, 804.

407 Lord Wright, 'War Crimes under International Law', n 390 above, 47.

408 Wright, n 387 above, 802.

409 ibid 804

410 ibid.

411 ibid 803

${ }^{412}$ F. Gény, Méthode d'interprétation et sources en droit privé positif: Essai critique, 2 vols (Paris: L.G.D.J., rev. $2^{\text {nd }}$ ed, 1954 [1919; $1^{\text {st }}$ ed. orig. pub. 1899]) at II, 100

413 Wright, n 387 above, 802

414 ibid 802-803. For development of the connection Wright makes in the first half of this passage, see D. J. Ibbetson, 'Natural Law and Common Law' (2001) 5 Edinburgh L. Rev. 4.
} 
'[T] he only question' lawyers need ask about the totalitarian crime against peace 'is whether the crime can be punished on legal grounds, that is whether the offence has achieved the status of being forbidden by law.'115 So far as Wright was concerned, the status of international peace agreements at the end of World War II, along with the fact that natural law principles are embedded in the positive legal order, meant that this question had to be answered in the affirmative. ${ }^{416}$ The temptation to treat his turn to natural law as something akin to a denouement, while obvious enough, must be resisted. For even as a natural lawyer he was, at heart, an innovative traditionalist, upholding the law while seeking to add to its detail.

${ }^{415}$ Lord Wright, 'War Crimes under International Law', n 390 above, 49.

416 'The Common Lawyer [examining 'the sources of the International Law of War'] will be puzzled by the absence of previous Law Reports in which he finds his precedents, and also by the relative absence of Legislative Acts in which a great deal of his law is found. Perhaps this comparative absence of legislation will seem almost more grievous to the civil lawyer who finds the great part of his law in Codes. It may be that · after this last war ... the law of war will be lifted from an area of generality and be able by analysis and synthesis to formulate more specific rules. This will have been one result of the great campaign of war crime punishment which has followed the war.... [E]ven before this happened, there was certain material of a more or less tangible character. Apart from evidence of custom and practice, there were books of authority like Grotius and Vattel ... books of authenticity comparable to Coke or Blackstone in Anglo-American law. There were also certain international agreements, conventions or treaties which approximate in their importance to Legislative Acts.... The rules of law embodied in these Conventions have been tested in World War II which is ended. These Conventions may well be supplemented and revised, but their value cannot be overstated. They and the like are the nearest approach to legislation possible in the present state of international relations.' Lord Wright, 'Foreword', in United Nations War Crimes Commission, Law Reports of Trials of War Criminals, 15 vols (London: HMSO, 1949) at XV, pp.viixvii at xi-xii. 